\title{
"CONTROLE DE QUALIDADE DE IOGURTE COMERCIAL E ESTUDO DO PODER ACIDIFICANTE DE SUAS CULTURAS LÁTICAS."
}

\section{"ROSELI DO CARMO FREITAS DA SILUR" \\ Química}

Orientador: João Gustavo Brasil Caruso

\begin{abstract}
Dissertação apresentada à Escola Superior de Agricultura "Luiz de Queiroz", da Universidade de são Paulo, para obtenção de título de Mestre em Agronomia. Area de concentração: Ciência e Tecnologia de Alimentos.
\end{abstract}

PIRACICABA

Estado de Sāo Paulo - Brasil

Janeiro - 1991 
Ao Mario Luiz, Maria Carolina, Paulo Henrique, Mónica e a meus pais: Laurindo e Leonirce com muito amor. DEDICO 


\section{AGRADECIMENTOS}

- A Deus

- AoProf. Dr. João Gustavo Brasil Caruso, pela orientação , amizade, confiança e apoio demonstrados durante a execução deste trabalho.

- Ao Prof. Dr. Antonio Joaquim de Oliveira pelas sugestões e incentivos à este trabalho.

- A Cleomar, Roque e Vera pela amizade e boa convivência no laboratório.

- A Célia Regina pela grande amizade e ajuda durante o desenvolvimento deste trabalho.

- Ao Conselho Nacional de Pesquisa (CNPq), pela bolsa conce dida.

- Ao Mario Luiz pelo grande incentivo e amor demonstrado.

- A todos que direta ou indiretamente, contribuiram, na execução deste trabalho. 


\section{SUMARIO}

IISTAS DAS TABELAS ..................... iv

RESUMO ................................ v v

SUMMARY $\ldots \ldots \ldots \ldots \ldots \ldots \ldots \ldots \ldots \ldots \ldots \ldots \ldots \ldots \ldots \ldots . \ldots \ldots \ldots$

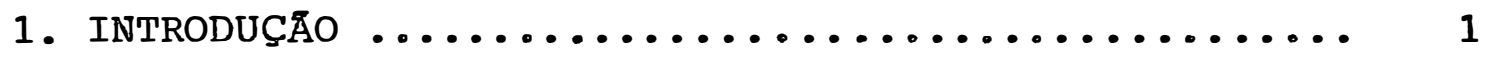

2. REVISAO BIBLIOGRĂFICA ......................... 5

1 . Composição e acidez ..................... 5

2. Culturas láticas do iogurte .............. 10

3. Relação cocos:bastonetes .................. 17

4. Meios de cultura para enumeração dos L. bulgari-

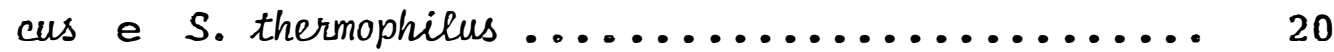

5. Contaminantes ....................... 30

3. MATERIAIS E METODOS ........................ 34

Parte I: Análises do iogurte comercial.......... 34

1. Coleta das amostras .................... 34

2. Preparo das amostras ................... 34

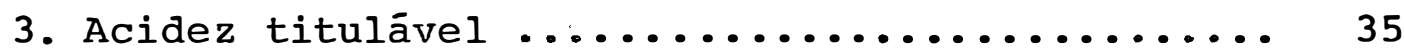

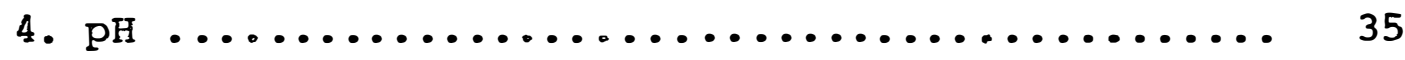

5. Peso liquido .......................... 35

6. Contagem de S. thermophilus e L. bulgaricus ...... 36

7. Contagem de coliformes totais ............. 36

8. Contagem de fungos e leveduras ............ 37

9. Isolamento e purificação dos microrganismos lá-

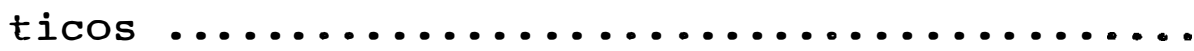


10. Identificação dos microrganismos ........... 38

10.1. Identificação de L. bulgaricus .......... 38

10.2. Identificação de $S$. thermophilus.......... 38

Parte II: Crescimento populacional e produção de ácí do pelos microrganismos isolados ....... 39

1. Definição de temperatura ................. 39

2. Produção de ácidos pelos pares estreptococo lacto bacilo.............................. 40

3. Acidificação e pós-acidificação ............. 40

4. Crescimento do L. bulgaricus e S. thermophilus ..... 41

4. RESULTAdOS E DISCUSSסES ...................... 42

1. Peso líquido, acidez titulável e pH dos iogurtes adquiridos no comércio .................... 42

2. Contagens de L. bulgaricus, S. thermophilus, coliformes fungos e leveduras para os iogurtes adquiridos no comércio ............................. 45

3. Identificação dos $L$. bulgaricus .............. 48

$\therefore$ Identificação dos S. thermophilus ............. 49

5. Produção de ácido pelos L. bulgaricus e S. thermophilus isolados $\ldots \ldots \ldots \ldots \ldots \ldots \ldots \ldots \ldots \ldots \ldots \ldots \ldots \ldots \ldots$

6. Produção de acidez pelos pares estreptococos-lactobacilos ............................ 51

7. Desénvolvimento da acidez durante o período de incubação (acidificação) e de armazenamento (pós-acidificação), para os trēs pares de cultu-

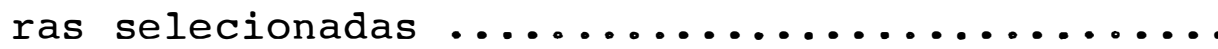

8. Números de lactobacilos e estreptcocos nos iogur tes durante o período de incubação e o período 
de armazenamento $\ldots \ldots \ldots \ldots \ldots \ldots \ldots \ldots \ldots \ldots$

5. CONCLUSÕES ............................. 62

6. REFERENCIAS BIBLIOGRAFICAS $\ldots \ldots \ldots \ldots \ldots \ldots \ldots \ldots 64$ 


\section{LISTA DE TABELAS}

\section{TABELA}

1 Valores médios obtidos para peso líquido, aci dez titulável e $\mathrm{pH}$, nos iogurtes adquiridos no comércio........................

2 Valores médios obtidos para as contagens de S. thermophilus, L. bulgaricus, coliformes, fungos e leveduras para os iogurtes adquiridos no comércio .......................

3 Identificação do L. bulgaricus .............

4 Identificação do S. thermophilus ............

5 Desenvolvimento da acidez titulável $1 \%$ ac. lá tico) a $37^{\circ} \mathrm{C}$ e $42^{\circ} \mathrm{C}$ pelas culturas isoladas...

6 Desenvolvimento da acidez titulável e $\mathrm{pH}$ pelas cultur s mistas, a $42^{\circ} \mathrm{C} \ldots \ldots \ldots \ldots \ldots \ldots$

7 Desenvolvimento da acidez titulável e pH duran te o período de incubação a $42^{\circ} \mathrm{C} \ldots \ldots . . . . . .53$

8 Desenvolvimento da acidez titulável e pH duran te o periodo de armazenamento a $7^{\circ} \mathrm{C} \ldots . . . .$.

9 Número de lactobacilos e estreptococos no iogurte LCSD durante o período de incubação e o período de armazenamento..................

10 Número de lactobacilos e estreptococos no iogurte LCSA durante o período de incubação e o período de armazenamento

11 Número de lactobacilos e estreptococos no iogurte LASD durante o período de incubação e o

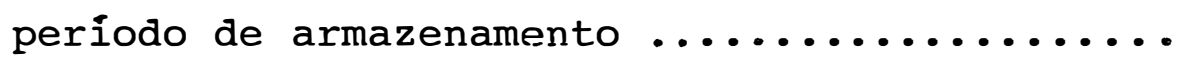




\title{
${ }^{a C O N T R O L E ~ D E ~ Q U A L I D A D E ~ D E ~ I O G U R T E ~ E ~ E S T U D O ~ D O ~ P O D E R ~ A C I D I F I-~}$ CANTE DE SUAS CULTURAS LÁTICAS."
}

\author{
Autora: Roseli do Carmo Freitas da Silva \\ Orientador: Prof. Dr. João Gustavo Brasil Caruso
}

\section{RESURMO}

Amostras de quatro marcas diferentes de iogur te disponíveis no comércio de Piracicaba, SP, foram coletadas durante cinco meses para análises de verificação do peso líquido, acidez titulável, pH, número de coliformes, fungos e leveduras, bem como, isolamento, purificação, identifica ção e estudo do poder acidificante das bactérias láticas prẹ sentes.

Os resultados obtidos demonstraram variação no peso líquido dos iogurtes comerciais, com $75 \%$ das amostras abaixo do peso declarado na embalagem. Os valores de acidez titulável variaram entre 1,10 e 1,54용 de ácido lático e o $\mathrm{pH}$ entre 3,87 e 4,42 .

As análises microbiológicas revelaram que, pa ra uma das marcas, durante os três primeiros meses não foram detectadas bactérias láticas viáveis, enquanto todas as demais amostras apresentaram números desses microrganismos den tro dos limites relatados na literatura. As contagens de coliformes revelaram que $50 \%$ das amostras analisadas apresenta 
ram valores acima de $10 \mathrm{u} . f . c . / m l d o$ produto; para fungos e leveduras, $30 \%$ das amostras apresentaram mais que $10 \mathrm{u} . \mathrm{f} . \mathrm{c} . \mathrm{ml}$ do produto.

As bactérias láticas de cada amostra foram isoladas, purificadas e identificadas, confirmando tratar-se de $L$. bulgaricus e $S$. thermophilus em todos os iogurtes amostra dos. As culturas puras isoladas foram testadas quanto ao seu poder acidificante isoladamente e em culturas mistas resultantes dos pareamentos dos lactobacilos com os estreptoco $\cos$.

As três culturas mistas que apresentaram $n$ melhor poder acidificante foram testadas quanto ao desenvolvimento da acidez durante um periodo de 4 horas de incubaçãn a $42^{\circ} \mathrm{C}$ e, a seguir, durante um periodo de 31 dias de armazenamento a $7^{\circ} \mathrm{C}$, utilizando-se leite desnatado, reconsti tuído com $12 \%$ SNG e esterilizado. 

LACTIC CULTERES.

Author: Roseli do Carmo Freitas da Silva Adviser: Prof. Dr. João Gustavo Brasil Caruso

\section{SLAAMARY}

Samples of four different brands of commercial yoghurt available in Piracicaba, SP, were collected in five months for verification analysis of the net weight, titrable acidity, pH, coliform, mold and yeast numbers, and for isolation, purification, identification of the lactic bacteria presented as well.

The results obtained showed a variation in the commercial yoghurt net weight, with 758 of the samples below the weight declared in the wrappings. The titrable acidity values varied between 1,10 and 1,548 of lactic acid and the $\mathrm{pH}$ between 3,87 and 4,42 .

The microbiological analysis revealed that, for one of the brands, during the first three months viable lactic bacteria were not detected, while the other samples showed these microorganism numbers within the limits related in the literature. The coliform enumeration revealed that $50 \%$ of the analysis samples, showed values over $10 \mathrm{cfc} / \mathrm{ml}$ of the product, as to molds and yeasts, $30 \%$ of the samples showed more than $10 \mathrm{cfc} / \mathrm{ml}$ of the product. 
The lactic bacteria of each sample were isolated, purified and identified, confirming to be L. bulgaricus and S. thermophilus in all the yoghurts examined. The isolated pure cultures were tested as to its acidifying power isolatedly and in mixed cultures resulting from the pairs of lactobacilli with streptococci.

The three mixed cultures, wich showed the best acidifying power, were tested as to the acidity development during a period of four hours of incubation at $42^{\circ} \mathrm{C}$ and then, during a period of 31 days of storage at $7^{\circ} \mathrm{C}$ using reconstituted with $12 \%$ SNG and sterilized skimmed milk. 


\section{INTRODUSCAO}

A qualidade dos produtos alimentícios e a sua influência sobre a nutrição e a saúde humana vem merecendo lugar de destaque nos meios científicos. Essa preocupação se deve ao grande número de produtos alimentícios exis tentes e a uma tendência atual de se ingerir produtos natú rais.

Experiências feitas em quase todo $\circ$ mundo, destacando-se a Europa, constataram que produtos lácteos, acidificados artificialmente através de culturas especiais, são de um valor incalculável para o nosso organismo, pois os microrganismos acidificantes tem a propriedade de desobs truir o intestino, eliminando os resíduos aderentes ao mesmo, facilitando a função intestinal e automaticamente combatendo a fermentação anormal de nosso organismo, geralmente originária do excesso de alimentação.

O iogurte com seus 0,5 a 5 milhões de micror ganismo por grama, é um excelente produto vivo (KURMAN, 
1977). O iogurte é resultante da fermentação do açúcar do leite, a lactose, por bactérias láticas, tradicionalmente S. termophilus e L. bulgaricus.

A elaboração do iogurte é uma técnica que se expande cada vez mais no mundo inteiro, e, de um preparo originalmente simples, vem se transformando em um processo bastante sofisticado. Entretanto, com a rápida incorporação deste produto aos hábitos alimentares, a competição in dustrial desencadeou a busca de novos processos que possibilitassem a redução dos custos de fabricação, sem prejuízo ḍa qualidade do produto.

A pesquisa objetivando aumentar o período de conservaçao ultrapassando o prazo normal de 2 a 4 semanas. vai de encontro à imagem do produto fresco e do desejo ios consumidores.

A manufatura do iogurte requer cuidados do começo ao fim. Os fatores importantes para que o produto final seja de qualidade satisfatória, são: frescor do leite, equilíbrio entre as culturas, temperatura de incubação, rapidez no empacotamento e resfriamento. Em adição, o processo de fermentação deve ser monitorado cuidadosamente pa ra que. a acidez não atinja um grau inaceitável para o consumidor, WELKER (1986).

A relação de simbiose entre S. thermophilus e L. bulgaricus durante a acidificação do leite por culturas mistas, comumente referidas como bastonetes e cocos, foi 
extensivamente estudada (BAUTISTA et alli, 1966 ; DRIESSEN et alli, 1982a; LABRAPOULOS et alli, 1982; PETTE e LOLKEMA, $195 \mathrm{Ca}$; SANKAR e DAVIES, $197 \mathrm{7J}$, mas poucos estudos sobre a viabilidade e poder acidificante das culturas durante a es tocagem do iogurte foram feitos (SANDINE e MATALON, 1986).

Para se obter um iogurte de boa qualidade as indústrias de laticínios que se dedicam a fabricação de iogurte, necessitam frequentemente renovar suas culturas, ou mesmo recombiná-las. A combinação de diferentes linhagens de L. bulgaricus e. S. thermophilus permite conseguir iogur te com maior ou menor produção de acidez, aroma e retenção de soro.

o processo de fabricação de iogurte, atual-. mente utilizado consiste no emprego de culturas microbiolo gicamente puras, selecionadas visando promover a fermentação desejada com um resultado tecnológico muito superior no que se refere à padronização da qualidade do produto resul tante. Nesse prociesso a flora lática natural normalmente é eliminada pela pasteurização e a fermentação passa a depen der exclusivamente da cultura lática adicionada como inócu 10.

Até o presente momento, a indústria de laticínios nacional tem dependido quase que exclusivamente de culturas láticas importadas, originárias de laboratórios internacionais especializados no isolamento, seleção e comercialização de culturas especificas para cada tipo de 
produto desejado. E esses laboratórios são localizados em países de condições ecológicas e tecnológicas bem diferentes do nosso. Portanto, é fácil de se deduzir as dificulda des de adaptação dessas culturas altamente especializadas frente às diferentes condições, não só climáticas mas principalmente higiênicas, onde as mesmas são expostas a mercê de contaminante altamente ativos e naturalmente adaptados as condições adversas.

Com o desenvolvimento de uma tecnologia de isolamento, identificação e estudo do poder acidificante de culturas láticas, poder-se-á elimiar o ônus que as culturas importadas representam, além de tentar minimizar $\mathbf{a}$ pós-acidificação que ocorre em iogurtes comerciais.

Em vista disso, objetivou-se no presente tra balho, o estudo de algumas características químicas, físicas, físico-químicas e microbiológicas de iogurtes de dife rentes marcas comerciais disponiveis no comércio, além do isolamento e caracterização das culturas láticas desses iogurtes comerciais e o posterior estudo do crescimento e produção de ácido por essas culturas puras e combinadas en tre si, para escolha dos melhores pares e então estudar o poder pós-acidificante durante a armazenágem. 


\section{REVISATO DE LITERATURA}

\section{Composição e acidez}

o iogurte dentro da sua zona de origem, penín sula balcânica, era preparado com leite de cabra e com a ajuda de culturas naturais. Pesquisas desde o início do século nos indicam que em fermentos láticos tais culturas são representadas por Lactobacillus yugurti e Lactobacillus bulgaricus. A cultura natural foi igualmente substituida por uma associação de bacilos e estreptococos termofílicos e, nos últimos tempos, numerosas pesquisas foram reservadas à explicação das funções de L. bulgaricus e S. thermophilus na produção e na qualidade do iogurte atual.

Segundo HAMANN e MARTH (1984b), a composição do iogurte é aproximadamente a mesma do leite da qual ele é feito.

Estudos realizados por DUITSCHAEVER et alli (1972) demonstraram grande variação na composição química de iogurtes comerciais. Os autores avaliaram 152 iogurtes de 
Ontário, Canadá, e verificaram que geralmente não existe iogurte de composição uniforme. O peso líquido chega a variar até $7,2 \%$. Os valores do $\mathrm{pH}$ variam de 3,27 a 4,53 com um valor médio de 3,91 .

KROGER e WEAVER (1973), analizaram iogurtes comerciais da região central da Pensilvânia (41 de frutas e 3 naturais). A grande variação da composição química tam bém é problema. o peso líquido tem uma variação em torno de $6,87 \%$. Os estudos também demonstram grandes variações no pH, proteína, sólidos totais, gordura e calorias.

Estudos realizados por RICHMOND et alli(1979) em iogurtes do mercado de Michigan, mostraram para iogurte. com frutas, 4,34\% de proteína, 2,34\% de gordura, 25,88\% de sójidos totais e pH 4,01. Para iogurte natural os valores foram 5,68\% proteinas, 2,86\% de gordura, 16,90\% de sólidos lotais e pH 4,23. Os dados mostram que apenas 10,6\% das amostras tinham o peso líquido abaixo do declarado.

FERREIRA e CHAVES (1981) analisaram iogurte produzido na Zona da Mata, Minas Gerais, quanto aos teores de gordura, sólidos totais, proteína, pH, acidez titulável, valor calórico e peso líquido. Os resultados das análises químicas são comparáveis aos encontrados na literatura, com exceção dos valores relativos a acidez, que estão. acima. Segundo esses autores certo grau de acidez é desejável no iogurte, porem super-acidificação do produto é indesejável, visto que conduz a separação dẹ soro e de 
terioração da sua consistência e viscosidade.

HUMPHREYS e PLUNKETT (1969) recomendam um $\mathrm{pH}$ final em torno de 3,7 - 3,8 e acidez titulável final em torno de $1,0-1,25 \%$.

Uma acidez mínima de 0,7\% de ácido lático no iogurte é necessária para a sua venda, segundo SELLARS e BABEL (1970). No caso dos sólidos contidos no leite influenciarem na acidez titulável, esses autores recomendam uti lização do $\mathrm{pH}$ como critério de acidez e um $\mathrm{pH} 4,0$, parece ser o mais aceitável para o consumo.

GINSLOV (1970) sugere uma acidez de $1,2 \%$ de ácido lático.

$0 \mathrm{pH}$ do iogurte comercial geralmente varia em Grno de 3,7 a 4,3, segundo DAVIS e McLACHLAN (1974).

De acordo com LUCK e MOSTERT (1971), iogurte com pH 3,9 - 4,1 tem um pessímo paladar devido à alta acider:

A acidez do iogurte é devido parte a acidez natural do leite e parte a acidez desenvolvida pela flora bacteriana. E importante que a acidez desenvolvida durante a produção seja cuidadosamente controlada, para que um excesso de acidez não se desenvolva durante a estocagem re frigerada. Estudo desenvolvido por ROBINSON e TAMINE(1976), comparam métodos para determinação de acidez titulável em iogurte. De acordo com esses autores, na "coalhada bulgạ ra" a acidez varia em torno de 0,9 a $1,48 \%$ de ácido láti- 
co e no iogurte a acidez é de 0,72 a 1,17\% de ácido lático. Estudos realizados por TERRA et alli (1977), mostraram que 58,97\% das amostras analisadas apresentaram valores de $\mathrm{pH}$ superiores a 4,3 .

ACCOLAS et alli(1977) realizaram interessantes estudos sobre a variação na produção de ácido no leite por culturas láticas, sob diversas condições. Os estudos de monstraram que a armazenagem do iogurte a $8^{\circ} \mathrm{C}$, como é comer cialmente praticada na França, é insatisfatória para a conservação do produto, devịdo a capacidade das culturas de continuar a acidificação a baixas temperaturas. Muitas bactérias do ácido lático tem a capacidade de continuar a acidificação depois que a fase estacionária de crescimento é alcançada. Possíveis soluções propostas para conter esse efeito foram o resfriamento rápido a temperaturas por volta de $0^{\circ} \mathrm{C}$ ou o uso de culturas mistas que tenham um baixo poder acidificante a temperaturas de refrigeração.

SALJI e ISMAIL (1983), estudaram a relação entre a acidez inicial do iogurte natural e as mudanças des sa acidez durante o armazenamento refrigerado. O armazenamento foi de 3 semanas a $4^{\circ} \mathrm{C}$ e $7^{\circ} \mathrm{C}$, mudanças na acidez são mais pronunciadas a $7^{\circ} \mathrm{C}$ quando comparadas a $4^{\circ} \mathrm{C}$. Segundo os autores as maiores mudanças na acidez ocorreram na primeira semana de armazenamento.

Estudos realizados por SALINAS (1984a), na microflora de iogurte comercial durante a armazenagem a $7^{\circ} \mathrm{C}$ 
por.12, 20, 30 e 40 dias, mostraram que o tempo máximo de armazenagem para o iogurte comerciàl é de 3 semanas. Segundo TAMINE et alli (1987), o pH do iogurte pode ser relacionado com o tipo de leite utilizado. MARTINS e LUCHESE (1988a) estudaram o comportamento acidificante em temperatura de processamento e en condições de armazenamento, de 30 associações de cepas de S. thermophilus e L. bulgaricus, isolados de quatro marcar comerciais de iogurte, visando estabelecer critérios de seleção.

De acordo cóm JORDANO et alli (1988) as mu danças de $\mathrm{pH}$ e acidez titulável são mais marcantes durante os onze primeiros dias, que entre onze e vinte e um dias de armazenamento.

Amostras de iogurte natural foram testadas 48 horas após serem produzidos e depois 15,24 e 30 dias armazenadas a $5-7^{\circ} \mathrm{C}$ e $11-13^{\circ} \mathrm{C}$. $\mathrm{O} \mathrm{pH}$ decresce durante a armazenagem a $5-7^{\circ} \mathrm{C}$ e atinge um minimo depois de 24 dias; enquanto que para as amostras armazenadas a 11 $13^{\circ} \mathrm{C}$, o $\mathrm{pH}$ decresce rapidamente de acordo com DIAZ et alli (1989) .

SINHA et alli (1989) enumeraram os fatores que poderiam ser responsáveis pelo excesso de acidez desenvolvido durante a armazenagem de 6 marcas de iogurte co mercial mantidos por 4 semanas a 4,7 e $10^{\circ} \mathrm{C}$. Foram analizadas mudanças de acidez $(\mathrm{pH})$, contagem de L. bulgaricus e 
S. thermophilus, coliformes, fungos e leveduras. $0 \mathrm{pH}$ varia de 4,14 para 3,6 a $4^{\circ} \mathrm{C} ; 4,11$ para 3,72 a $7^{\circ} \mathrm{C} ; 4,08$ para 3,68 a $10^{\circ} \mathrm{C}$ indicando a possibilidade do $\mathrm{pH}$ do iogurte ser menor que 4,0. A relação L. bulgaricus : S. thermophilus varia de 1:1 a 1:8. Coliformes, fungos e leveduras não são detectados durante o tempo de armazenagem. Segundo os autores a acidificação no processamento não deve ser muito intensa quando se trata de produção em larga escala, já que na prática a capacidade de resfriamento de uma usina pode ser limitada, o que não permitiria uma rápida. redução na temperatura de todo o produto. A capacidade de aci dificação dos microrganismos deve permitir, porém, que o processamento se faça dentro de um tempo razoável. A su peracidificação desenvolvida durante a armazenagem resulta em um sabor ácido forte, e isto é considerado um defei to. Os autores sugerem um $\mathrm{pH}$ final de 4.4 para o iogurte comercial.

\section{CuRturas läticas do iogurte}

O iogurte é resultado da alteração processada no leite através da fermentação da lactose por micrợ ganismos selecionados podendo ser tradicionalmente o L. bulgaricus e o S. thermophilus, e a estes microrganismos podem ser adicionados outros que com eles cresçam simbioti camente alterando ou conferindo características espera- 
das no produto. Durante a fermentação, a lactose se transforma em ácido lático, o pH do leite se aproxima do ponto isoelétrico das proteínas que então se precipitam, forman do assim a massa característica do iogurte. (BOTTAZzI et alli, 1977; FERREIRA, 1978).

o iogurte é fabricado principalmente de lei te de vaca empregando cultura mista de L. bulgaricus e S. thermophilus que se desenvolvem em simbiose. Os microrga nismos são responsáveis pela fermentação lática e formação do aroma típico do produto. $\mathrm{O}$ pH e temperatura ótimos para o crescimento do $S$. thermophilus são respectivamente 6,8 e $38^{\circ} \mathrm{C}$, ao passo que para o L. bulgaricus são 6,0 e $43^{\circ} \mathrm{C}$. A simbiose entre as bactérias está relacionada com o quantidade inoculada, temperatura de incubação e tempo de incuba ção de acordo com SILVA (1974).

Na literatura, o crescimento associativo das duas bactérias do iogurte é chamado simbiose, mas de acordo com GALESLOOT et alli (1968), só existem trabalhos demonstrando a estimulação do $S$. thermophilus pelo L. bulgaricus e não a estimulação do L. bulgaricus pelo S. thermophilus.

Os autores demonstraram que $S$. thermophilus também estimula o L. bulgaricus pela produção de um fator que é equivalente ou pode ser substituído pelo ácido fórmico.

A existência de interação entre as duas bactérias do iogurte, L. bulgaricus e $S$. thermophilus, favo- 
ráveis ao desenvolvimento da associação bacteriana, à acidî ficação e à formação do aroma, além da formação de coagulo, foi demonstrada por ACCOLAS et alli (1971), BAUTISTA et alli (1966), GALESLOOT et alli (1968), HAMDAM et alli (1971) MEILKEJOHN (1977), MOON e REINBOLD (1976) e VERINGA et alli (1968) .

O L. bulgaricus, atuando sobre as proteínas do leite, libera aminoácidos que estimulam o desenvolvimento de S. thermophilus (LEE et alli, 1974; PETTE e LOLKEMA, 1950c) , que por sua vez produz ácido fórmicol(SURTYARACHCHT è: FTEET, 1981; VERINGA et alli, 1968) e dióxido de carbono (DRIESSEN et alli, 1982à) necessário ao desenvolvimento do L. bulgaricus. A reciprocidade desta simbiose parece estar ligados à proporção das duas espécies, durante a fermentação, alcançando na primeira etapa a proporção de 3:1 de Streptococcus para Lactobacillus, começando o último a predominar nas fases seguintes (SURIYARACHCHI e FLEET; 1981).

Segundo DAVIS (1975), o S. thermophilus elimi na o oxigênio e produz condições favoráveis de acidez para - L. bulgaricus. Em geral os estreptococos do leite crescem melhor a pH 6,5, com o crescimento parando quando o pH atin ge 4,2 - 4,4 e os lactobacilos crescem melhor a $\mathrm{pH} 5,5$ com o crescimento parando em $\mathrm{pH} 3,5-3,8$. Segundo o autor a questão do padrão microbiológico é muito difícil, mas como muitos consumidores esperam que o iogurte seja uma cultura viva, um padrão razoável seria não menos que $10^{?}$ de 
L. bulgaricus e S. thermophilus colônias/grama. Sem se levar em conta a diferença na composição quỉmica, o iogurte natural e o iogurte com frutas são basicamente os mesmos, do ponto de vista microbiológico.

As culturas de iogurte podem ser selecionadas pela sua habilidade de crescer em associação e de produzir o sabor balanceado desejado.Esse sabor é geralmente ad quirido tanto pelo controle de crescimento, como pela razão entre os dois microrganismos que deve ser mantida na ordem de 1:2 - 2:1. Um procedimento simples é controlar o crescimento pela temperatura e o tempo de incubação; temperaturas mais altas e tempo de incubação longo favorecem o lactobaci 1o.

O trabalho realizado por ACCOLAS et alli (1977) sobre culturas individuais de Streptococcus e Lactobacil lus mostram que a atividade acidificante máxima ocorre a uma temperatura de $42-45^{\circ} \mathrm{C}$, para o Streptococcus e ao redor de $44-46^{\circ} \mathrm{C}$ para o Lactobacillus. A cultura mista composta por Streptococcus e Lactobacillus apresenta atividade acidificante máxima no intervalo de temperatura correspondente a 35 $43^{\circ} \mathrm{C}$. A acidificação ocorre exponencialmente durante o crescimento da cultura mista e prossegue ainda ativamente quando cada um dos organismos atinge a população máxima. Segundo os autores a concentração da cultura a ser utilizada será função: do seu poder acidificante; do tempo de incubação deseją do; da riqueza em células bacterianas; da fase de crescimen- 
to na qual se encontra a cultura; da relação Lactobacillus : Streptococcus; do teor de sólidos, uma vez que, quando este valor é muito elevado, a acidificação se faz mais rapidamente e a porcentagem de inoculação deve ser mínima, com o objetivo de impedir uma acidificação muito intensa, e normalmente se trabalha com $3 \%$ ou menos.

De acordo com os autores, os fabricantes buscam, de preferēncia, culturas mistas ativas de modo que possam obter uma acidificação mais rápida possível $\left(90^{\circ} \mathrm{D}\right.$ a $100^{\circ} \mathrm{D}$ em 3 à 4 horas) à uma temperatura elevada próxima de $45^{\circ} \mathrm{C}$.

De acordo com KURMANN (1977), para a incubação é necessário procurar um tempo mínimo de 3 horas,pa ra assegurar a formação de substâncias aromáticas suficientes e para não arriscar uma super acidificação até o resfriamento do iogurte. Teoricamente a temperatura de cultivo simbiótico é de $45^{\circ} \mathrm{C}$. Na prática trabalha-se com temperaturas mais baixas, de 40 a $45^{\circ} \mathrm{C}$. Segundo os autores qualquer pesquisa no sentido de melhorar a qualidade do iogurte, deve ser realizado pela adaptação a mutação das culturas originais, como por exemplo, a produção de diacetil, de mucus, a multiplicação a uma temperatura abai xo da ordinária, uma fraca pós-acidificação. Uma exceção poderia ser feita pela substituição do L. bulgaricus por L. acidophilus e/ou L. bifidus, com a finalidade de melhor controlar a pós-acidificação do iogurte. 
De acordo com TAMINE e DEETH (1980), O $S$. thermophilus cresce rapidamente no início da fermentação utilizando aminoácidos essenciais produzidos pelo L. bulgaricus. S. thermophilus produz ácido lático, que diminue o $\mathrm{pH}$ e torna o meio ideal para o crescimento de L. bulgaricus além de produzir ácido fórmico que estimula o crescimento do L. bulgaricus.

Várias razões são apresentadas por VIEIRA (1981) ressaltando a importância das bactérias láticas na formação do iogurte: a fórmação do ácido lático dá. uma . proteção as substâncias alimentícias devido à inibição das bactérias que causam a putrefação, o ácido lático é um agente de conservação; a fermentação lática "aromatizante" permite a obtenção de produtos ácidos com sabor agradável; produção de substâncias inibidoras, respoñsáveis pela seleção das espécies e a produçãọ de viscosidade.

BOVILLANE E DESMAZEAUD (1981) estudaram o comportamento de associações de L. bulgaricus e S. thermophilus em relação à acidificação no processamento, no armaze namento e produção de substâncias aromáticas, concluiram que as respostas obtidas podem ser muito variáveis, poden do algumas associações serem muito acidificantes no processamento e não no armazenamento, e vice-versa.

Trabalhos realizados por SINGH e SHARMA (1982) ressaltaram a importância da seleção adequada dos microrganismos para a obtenção de uniformidade e estabi- 
lidade no produto, especialmente em termos de proteólise e ácido lático. A produção de ácido lático no processamento do iogurte deve ser observada em dois planos diferentes; em um existe aquela acidificação necessária ao processamento do produto, em outro existe a pós-acidificação, ou seja , aquela acidificação que ocorre de modo lento, no armazenamento refrigerado.

Normalmente a população de microrganismos vivos no iogurte aumenta logo após a fabricação, diminuindo posteriormente durante o armazenamento refrigerado. A população viva de $S$. thermophilus e L. bulgaricus está em tor no de $100 \mathrm{milhões/g} \mathrm{no} \mathrm{iogurte} \mathrm{natural} \mathrm{e} \mathrm{no} \mathrm{iogurte} \mathrm{de} \mathrm{mo-}$ rango, quando armazenados a $5^{\circ} \mathrm{C}$ por 60 dias segundo HAMANN e MARTH (1984b). Quando o produto é armazenado a $10^{\circ} \mathrm{C}$ esse número cai muito, segundo os autores.

Segundo GARCIA e OLIVEIRA (1985) no processo de fermentação atualmente utilizado emprega-se culturas microbiologicamente puras selecionadas, visando promover a fermentação desejada com um resultado tecnológico muito su perior no que se refere a padronização da qualidade do pro duto resultante. Nesse processo, a flora do leite é eliminada pela pasteurização e a fermentação passa a depender exclusivamente da cultura lática adicionada como inóculo. Segundo RADKE-MITCHELL e SANDINE (1986) a compatibilidade de S. tehrmophilus e L. bulgaricus durante 0 crescimento associativo é dependente de uma temperatura ótí 
ma de crescimento.

De acordo com MARTINS e LUCHESE (1988b) as bactérias do iogurte podem ser desenvolvidas separadainente e inoculadas em proporções definidas ao leite a ser processado. A manipulação destas culturas requer especialização, técnica e conhecimento de vários fatores intrínsecos aos diferentes microrganismos, como as diferentes tempera turas ótimas de crescimento, a capacidade de crescimento associativo, as diferentes velocidades de crescimento e as condições necessárias para que se mantenha o balanço essencial entre os dois microrganismos. Segundo os autores na seleção de linhagens de $L$. bulgaricus e S. thermophilus a determinação da compatibilidade de crescimento associativo é muito importante, jois deste modo pode-se evitar a utili zação concomitante dẹ linhagens que apresentem associação antagônica, o que prejudicaria a qualidade do produto final

\section{Relação cocos:bastonetes}

Na indústria de derivados do leite S. thermophilus é comumente referido como "cocos" e L. bulgaricus como "bastonetes".

Alguns países europeus tem proposto padrões para o conteúdo bacteriológico do iogurte. Dessa maneira, padrões para viabilidade de L. bulgaricus e $S$. thermophilus e a razão bastonetes: cocos são importantes na determina ção das propriedades organolépticas do iogurte. Essa razão 
deve ser de 1:1 para que a qualidade do produto seja alta (ACCOLAS, 1977; HAMANN e MARTH, 1984a e 1984b; HUMPHREYS e PLUNKETT, 1969; LABRAPOULOS et alli, 1982; LEE et alli , 1974; RADKE-MITCHELL e SANDINE, 1984; RASIC e KURMANN, 1978) ,

PETTE e LOLKEMA (1950d) sugerem uma relação de 1:1, bastonetes : cocos para o iogurte depois da incubação e resfriamento. SELLARS e BABEL (1970) recomendam uma similar relação para as bactérias do iogurte.

De acordo com PETTE e LOLKEMA (1950b) a pro porção de bastonetes e cocos no produto final é influencia do pela temperatura de incubação, acidez da cultura e taxa de inoculação.

PETTE e LOLKEMA (1951), estudando os fatores que afetam a proporção dos componentes da cultura látí ca, concluiram que a manutenção de um bom equilíbrio entré as duas espécies bacterianas de culturas mistas, durante as sucessivas repicagens, é uma técnica desejável, e uma rela ção 1:1 de Lactobacillus e Streptococcus é geralmente considerada ótima (DAVIS et alli, 1971; MOON et alli, 1975; PETTE e LOLKEMA, 1950b) .

o controle de proporção entre L. bulgaricus e S. thermophilus segundo DEMETER (1969) é de especial importância, devendo ser encontrado ao redor de 100 Lactobacillus para cada 120 - 200 Streptococcus. Esta proporção se altera em favor das termobactérias, ao serem semeadas maiores 
quantidades destas ou ainda devido ao aumento de temperatura, determinando uma acidez bem mais intensa.

STOCKLIN (1969) recomenda que a relação de bastonetes e cocos pode ser mantido em 1:1 ou 1:1,2.

Devido a importância da manutenção da relação desejável de $1: 1$ de bastonetes :cocos para a boa quali dade na fabricação do iogurte são necessárias certas técnicas para determinação relativa das proporções de $S$. thermophilus e L. bulgaricus em crescimento simbiótico (DAVIS et alli, 1971; LEE et alli, 1974).

Estudos sobre o equilíbrio da flora, $\mathrm{pH}$ e acidez de iogurte comercializado em Santa Maria, RS, foi realizado por TERRA et alli (1977). Das amostras 39,73\% apresentaram uma flora equilibrada, 41,02\% predominou $S$. thermophilus e 19,23\% predominou L. bulgaricus.

A manutenção de um bom equilíbrio entre as duas espécies bacterianas das culturas mistas, durante sucessivas substituições, é um processo de tentativas. Uma proporção lactobacilo/estreptococo próxima de 1 é, geralmen te, considerada como ótima por ACCOLAs et alli (1977) e pro cura-se mantê-la dentro das culturas sucessivas limitrófas do fermento e dentro do iogurte propriamente dito. Segundo os autores a conservação do equilíbrio entre lactobacilo/es treptococo, a produção de ácido e o aroma da cultura mista depende da escolha das linhagens, do ajustamento do inóculo, do tempo e da temperatura de incubação e eventualmente, do 
número de repicagens.

Estudos de MOON e REINBOLD (1976) concluiram que culturas de L. bulgaricus e $S$. thermophilus produzem maior quantidade de ácido quando juntos, que quando crescem separadamente. A competividade e o comensalismo entre esses microrganismos : ocorre a uma temperatura ótima de $37^{\circ} \mathrm{C}$ e quando a relação entre lactobacilos e estreptococos é de 2: 1 na inoculação.

A compatibilidade de $S$. thermophilus e $L$. bulgaricus durante o crescimento associativo foi determinado por RADKE - MITCHELL e SANDINE (1986), a contagem foi realí da em placas de Petri. Linhagens de $S$. thermophilus crescem em maior número de células que $\circ$ L. bulgaricusa 37,42 ou $45^{\circ} \mathrm{C}$, em $93.3 \%$ dos testes realizados com culturas mistas. A relação bastonetes: cocos obtida a 37,42 e $45^{\circ} \mathrm{C}$ é $1: 2,2$; $1: 1,18$ e $1: 2,4$ respectivamente.

GREEN e IBE (1987) sugerem uma relação de 1:1 para a relação de L. bulgaricus : S. thermophilus e recomen dam um crescimento máximo em torno de $10^{7}$ a $10^{8}$ u.f.c./ml depois de 4 a 8 dias de armazenamento a $10^{\circ} \mathrm{C}$.

4. Meios de cultura para èumeração dos L. bulgaricus e $S$. thermophilus

E interessante que se tenha disponivel um método simples e seguro para enumeração diferencial de bactérias de ácido lático em iogurte. 
EVANS e NIVEN (1951) desenvolveram um meio para microrganismos que requerem altos teores de tiamina, como Lactobacillus, Leuconostoc e Streptococcus. O meio continha "tween 80" para reduzir a lag-fase ou a fasé adaptativa dos microrganismos. Este meio foi inicialmente usado para lacto bacilos heterofermentativos, atualmente, no entanto, tem sido usado para contagem e isolamento de outros microrganis mos do grupo lático.

O meio de cultura desenvolvido por ELLIKER et alli (1956) tem sido considerado como o mais seletivo dos meios para contagem e isolamento de microrganismos láticos, provenientes de várias fontes.

Alterando a tradição da utilização de extratos proteícos vegetais nos meios de cultura para lactobacilos, DEMAN et alli (1960) propuseram um meio denominado MRS, a base de extratos de carne e levedura, proteose e peptona, como substratos nitrogenados. Esse meio tem sido, até hoje, amplamente aceito como um dos melhores meios de cultura para os integrantes do gênero Lactobacillus, por permitir o desenvolvimento de quase todas as linhagens do gênero. No entanto, sua seletividade é pequena, possibilitando o crescimento de outros microrganismos como estreptococos, levedu ras, etc.

SELLARS e BABEL (1970), MOCQUOT A HUREL

(1970) sugerem contagem em microscópio de culturas de iogur te para determinar a relação bastonetes:cocos. 
Para a enumeração de bactérias do iogurte, a contagem em microscópio é falha, pois não distingue bactéria morta de viva (DAVIS et alli, 1971; LEE et alli, 1974). Métodos microscópicos, entretanto, podem ser utilizados para determinação da razão de $S$. thermophilus e L. bulgaricus (DAVIS, 1970; JACQMAIN-GOLDSMIT e DARAR-LHOIS (1984)).

DAVIS (1970), utilizou o meio LAB para plaqueamento de $S$. thermophilus e $L$. bulgaricus do iogurte para es tudar a viabilidade dos mesmos quando estocados a $5^{\circ} \mathrm{C}$ por 28 dias. Segundo o autor apesar do meio ser satisfatório para enumeração e diferenciação das bactérias do ácido látị co, ele não as identifica.

PORUBCAN e SELLARS (1973) estudaram a influência da temperatura no tamanho e morfologia das colônias. Descreveram um meio preparado por adição de uma mistú ra de açúcares a um meio basal, antes do plaqueamento. Neste meio, L. bulgaricus formava colônias pequenas e difusas , enquanto o $S$. thermophilus formava colônias densas e bem separadas. Enumeração diferencial de bastonetes e cocos nesse meio, se torna difícil, pois é baseada na morfologia da colônia (MERMELSTEIN, 1982).

Um fator decisivo no isolamento de bactérias láticas é a escolha e utilização do meio de cultura a serem empregados. Existe um número muito grande de meios de cultụ ras que permitem o desenvolvimento de tais microrganismos (DAVIDSON e CRONIN, 1973 ; MARTH, 1978). No entanto, por 
serem muito ricos em nutrientes e conterem vários fatores de crescimento esses meios possibilitam o desenvolvimento de outros microrganismos não pertencentes ao grupo látiCO (MARTH, 1978).

LEE et alli (1974) descreveram um meio que contèm sacarose (maioria das linhagens de L. bulgaricus não fermenta sacarose), e lactose (que pode ser fermentado por S. thermophilus e L. bulgaricus). A adição adequada da combinação desses dois dissacarídeos a um meio basal, acen tuou o crescimento de S. thermophilus, que é capaz de mudar a côr de um indicador ácido-base, dando acentuada côr amarela às colônias. O L. bulgaricus cresce mais lentamente , pelo fato de poder fermentar apenas um dos açúcares e com isso produz menos ácido, formando colônias brancas. Enumeração diferencial de culturas bastonetes:cocos neste meio entretanto, era insatisfatória devido a variação das linha gens e difusão do ácido no meio.

DEAK (1974) propôs, para contagem e isolamento de bactérias láticas, o Lacto-agar, no qual, além de triptona, extrato de levedura, glicose e carbonato de cálcio, acrescentava-se sorbato de potássio $(0,7 \mathrm{~g} / 1)$ para inibir os microrganismos catalase-positiva e verde de bro inocresol como indicador da produção de ácido.

ROBINSON e TAMINE (1976) realizaram importan te trabalho sobre a qualidade microbiológica do iogurte, onde testam diferentes métodos e meios de culturas para as 
bactérias do iogurte, L. bulgaricus e S. thermophilus, e organismos patogênicos.

Para o isolamento de organismos do gênero Lactobacillus existe um número muito grande de meios de cultura já descritos, os quais apresentam uma grande variação de substâncias destinadas a aumentar sua seletividade. Mui tos dos meios propostos para esse fim, como o agar suco de tomate, agar suco de laranja e meio V.8 (SPECK, 1976), baseiam sua formulação em extratos vegetais acrescidos de fâ tores de crescimento e redução do pH para faixas abaixo de $5,8-6,0$. No entanto, ROGOSA et alli (1951) tinha proposto um meio contendo $2,5 \%$ de acetato de sódio, além de ácido acético, o que resultou num meio com boa seletividade.

HARRIGAN e MCCANCE (1976) indicaram o meio MRS para contagem e isolamento de lactobacilos de fontes que possuem uma grande variedade de microrganismos. Para isolamento de Streptococcus, os autores citam o meio agar lactato-vermelho neutro, cuja seletividade e eficiência po dem ser aumentados pela adição de 50 ppm de acetato de tálio, composto que inibe o crescimento de coliformes.

Um meio diferencial para $S$. thermophilus, baseado na adição de sal de tetrazolium e tirosina ao agar ST foi descrito por OTTOGALLI e GALLI (1978).

Quando incorporado glicerofosfato, ao agar, ocorria inibição no crescimento de L. bulgaricus, mas não de S. thermophilus. Enumeração diferencial baseada neste princí 
pio foi proposto por SHANKAR e DAVIES (1977a, 1978).

MORAES e PASSOS (1979) utilizaram métodos con vencionais de isolamento para separação dos microrganismos do iogurte, S. thermophilus e L. bulgaricus, dos contaminantes normalmente presentes no produto comercial. A metodologia empregada permitiu o isolamento e a identificação destes mí crorganismos a partir de iogurte comercial ou de culturas mistas. No isolamento do L. bulgaricus foi utilizado caldo Rogosa e agar Rogosa e na identificação efetuou-se provas de fermentação de açúcares sobre caldo MRS e prova de crescimento em meio de $2 \%$ e $4 \%$ de cloreto de sódio. 0 isolamento do S. thermophilus foi realizado em caldo vermelho neutro-lac tose-acetato de tálio e agar-vermelho neutro-lactose acetato de tálio e para identificação efetuaram-se provas de limite de crescimento a $45^{\circ} \mathrm{C}$ sobre caldo-levedura-glicose-extrato de carne, fermentação de maltose sobre caldo MRS contendo 2\% de cloreto de sódio.

TAMINE e DEETH (1980) desenvolveram um meio onde foi adicionado cloreto de trifeniltetrazolium e cisteí na ao meio basal de leite, na tentativa de realizar a enume ração diferencial da associação bastonetes e cocos.

Enumeração de bactérias de iogurte em meio agar é muitas vezes baseada na morfologia da colônia. Alguns meios de culturas para enumeração de bactérias de iogurte tem sido desenvolvidos (SURIYARACHCHI E FLEET, 1981) entretanto poucos métodos para enumeração diferencial de 
culturas bastonetes:cocos são descritos (DAVIS et alli, 1971).

Para BRACQUART (1981) existem poucos métodos desenvolvidos que permitem uma boa diferenciação das bactérias do iogurte. A contagem diferenciada das bactérias do iogurte pode ser feita de duas maneiras diferentes. Na primeira, cada microrgạnismo é cultivado separadamente em um meio seletivo, como os sugeridos por DEMAN et alli (1960), JOHNS et alli (1978), TERGAZHI e SANDINE (1975) e SHANKAR e DAVIES (1977a). Pode-se também utilizar um meio em que ambas bactérias cresçam, como o agar TPPY eriocromo-T; nes te meio a diferenciação baseia-se na coloração com negro de eriocromo-T das colōnias de $S$. thermophilus, mas não das colônias de L. bulgaricus.

CHAMBA et alli (1981) confirmaram a eficiên cia do acetato de tálio quando adicionado a diferentes meios para contagem da microflora acidificante de leite cru.

Dois meios para enumeração separada de bastonetes e cocos em iogurte foi desenvolvido por DRIESSEN et alli (1982b). S. thermophilus cresce em agar ST que contém sâ carose, enquanto que, L. bulgaricus forma colōnias difusas, irregulares, em agar LB.

Segundo COKER e MARTLEY (1982) numerosos meios de cultura tem sido propostos para a contagem seleti va de $S$. thermophilus e L. bulgaricus. As caracteristicas usa 
das para a diferenciação entre os dois microrganismos são a morfologia da colônia, açúcar fermentado e o pH do meio. De acordo com os autores o agar MRS pode ser modificado substituindo-se a glicose pela maltose como carboidrato fer mentável. Pelo fato do S. thermophilus não fermentar a malto se e alguns lactobacilos termofílos fermentarem, este meio pode ser usado para enumeração seletiva.

$$
\text { RADKE-MITCHELL e SANDINE (1984) reportaram }
$$

que nenhum meio diferencial desenvolvido deram resultados satisfatórios para todos as linhagens de Streptococcus e Lactobacillus quando testados em diferentes laboratórios.

$$
\text { HULL et alli (1984), utilizaram o meio Ml7 }
$$

a pH 6,8 para contagem de $S$. thermophilus e agar Rogosa para L. bulgaricus e L. helviticus var. jugurti.

O meio agar Elliker's e o agar Rogosa SL, são meios de cultura seletivas para L. bulgaricus, quando usados para determinar o número de $S$. thermophilus $e \quad L$. bulgaricus em iogurte comercial e iogurte manufaturados em laboratório, segundo HAMANN e MARTH (1984b).

Esses mesmos autores, HAMANN e MARTH (1984a) verificaram que os meios agar Elliker's e o "Hansen's Yogurt Agar" modificado permitiram contagens comparáveis nos dois meios, com uma boa diferenciação entre S. thermophilus e L. bulgaricus.

De acordo com GARCIA(1984), os procedimentos desenvolvidos para isolamento de bactérias láticas são 
muito parecidos, iniciando-se por um enriquecimento em cal do, leite ou leite suplementado por fatores de crescimento, indicadores, etc; sendo possivel fazer alterações na faixa de $\mathrm{pH}$ para beneficiar determinados grupos (ex lactobacilos), tratamento térmico (para S. thermophilus), plaqueamento e incubação em temperaturas que variam para os diversos grupos.

Para isolamento das bactérias láticas termo fílas (estreptococos e lactobacilos), após várias tentativas com diferentes meios. e diferentes condições de incubação, o meio agar APT foi o que apresentou os melhores resultados. As placas foram incubadas a $37^{\circ} \mathrm{C}$ por 24-48 horas. Após crescimento, colônias isoladas eram transferidas para leite tornassolado, seguindo-se incubação a $45^{\circ} \mathrm{C}$ até coagulação que normalmente ocorria dentro de 10 horas de acordo com GARCIA e OLIVEIRA (1985).

Segundo ANTUNES (1985), o meio de cultura APT, embora seja indicado para lactobacilos, permite o desenvolvimento de outros microrganismos. Para o isolamento de bactérias láticas o autor, utilizou o meio de cultura agar APT-S, desenvolvido a partir do agar APT, pela incorporação de $0,1 \%$ de sorbato de potássio, $0,5 \%$ de agar e con comitante redução do pH para 6,0 pela adição de ácido látí co comprovou-se que este meio teve um bom comportamento pa ra contagem e isolamento dos microrganismos do grupo látí co, apresentando uma eficiência seletiva nas condições uti 
lizadas.

A hidrólise do amido por $S$. thermophilus foi investigada por RADKE-MITCHELL e SANDINE (1986), mas essa característica é insatisfatória para desenvolvimento de um meio diferencial para bastonetes e cocos. Enumeração dí ferencial baseada na hidrólise da uréia por $S$. thermophilus era também investigada nesse estudo.

MATALON e SANDINE (1986) utilizaram agar Elliker's suplementado de $0,1 \%$ de Tween 80 e 2, 3, 5-clore to de trifeniltetrazolium a $50 \mathrm{\mu g} / \mathrm{ml}$ para contagem e diferenciação de bactérias do iogurte e cultura mistas de S. thermophilus e L. bulgaricus. O S. thermophilus produz colônia pequena e vermelha, enquanto o L. bulgaricus produz colônias grandes e brancas.

MARTINS e LUCHESE (1988b) realizaram estu-

dos para seleção de linhagens de L. bulgaricus e S. thermophilus para produção de iogurte, através da adaptação da técnica da sobre-camada semi-sólida para a detecção de antibiose en tre linhagens de L. bulgaricus e três linhàgens de $S$. thermophilus utilizando como meios de cultura agar MRS, agar LEE e agar M17.

Segundo ROHM et alli (1990) o número de

S. thermophilus e L. bulgaricus do iogurte natural varia em torno de $10^{8}$ u.f.C./g quando armazenado a $10^{\circ} \mathrm{C}$ por 10 e 20 dias depois da fabricação. Quando a temperatura e o tempo de armazenamento são elevados, há uma redução marcante na 
sobrevivência das bactérias do iogurte. A contagem do $S$. thermophilus é determinada por plaqueamento de amostras diluidas em agar M17, incubadas a $37^{\circ} \mathrm{C}$ por $48 \mathrm{~h}$, L. bulgaricus é controlado em agar MRS e incubado anaerobicamente a $48^{\circ} \mathrm{C}$ por 72 horas.

\section{Contaminantes}

SOULIDES (1986) reporta que leveduras que fermentam lactose do gênero Torulopsis são predominante mente responsáveis pela deterioração do iogurte natural.

Estudos realizados por RASIC e MITIC (1963) demonstraram que há um efeito mais forte de antagonismo de culturas bastonetes e cocos com linhagens de E. coli, S. aureus e B. subtilis do que cada linhagem sozinha. Segundo DAVIS (1970) a fabricação do iogu $\underline{\underline{r}}$ te é de excelente qualidade e o armazenamento sob refrige ração é feita corretamente $\left(5^{\circ} \mathrm{C}\right)$, quando encontra-se uma célula de levedura por grama.

Um estudo sobre a sobrevivēncia de colifor mes e S. aureus em iogurte revelou que estes organismos são rapidamente inativados neste produto (GOEL et alli , 1971; MINOR e MARTH, 1972).

De acordo com DAVIS (1975) as leveduras são os mais sérios contaminantes do iogurte com frutas e os fungos do iogurte natural. 
o controle da deterioração do iogurte por levedura torna-se um dos pontos principais em sua manufatura. Esta deterioração geralmente é. reconhecida pelo desenvolvimento de levedura sem flavor, baixa qualidade na textura devido a produção de gás e estufamento do recipien te (DAVIS e MCLACHLAN, 1974; KROGER, 1976).

Em virtude de ser um produto resultante da acidificação do leite por S. thermophilus e L. bulgaricus, o iogurte tem efeito antagônico no crescimento de numerosos organismos in vitro (RASIC e KURMANN, 1978; SINGH, 1983 ; YAZICIOGLU E YILMAZ, 1966).

De acordo com SURIYARACHCHI e FLEET (1981), 45\% do iogurte comercial encontrado no mercado, contêm aci ma de $10^{3}$ células por grama de levedura e um total de 73 linhagens de leveduras foram isoladas e identificadas. 0 crescimento de leveduras em iogurte está relacionado com a capacidade das leveduras crescerem a temperatura de refrigeração, de fermentarem lactose e sacarose e de hidrolizarem a caseína do leite. Segundo os autores, pelo fato de seu baixo pH, o iogurte é um meio ideal para o crescimento de leveduras, e inúmeros estudos são realizados ten do como objetivo a deterioração de iogurte por levedura.

ALEKSIEVA e MIRKOV (1981), reportaram sobre a ocorrência e crescimento de fungos e leveduras em iogurte.

Em estudos realizado por SINGH (1983), fil 
trado de culturas de $S$. thermophilus revelaram nenhum antagonismo com linhagens de S. aureus, E. coli, P. fragi e M. hlavus, enquanto filtrados de L. bulgaricus e uma mistura de cultura bastonetes e cocos inibiam o crescimento dos microrganismos testados. O mesmo resultado foi obtido numa investigação similar usando-se L. acidophilus em lugar de L. bulgaricus (SINGH E SHARMA, 1982).

GARCIA e FERNANDEZ (1984) estudaram a contaminação de iogurte por fungos. A presença, quantidade e espécies de fungos em iogurtes é muito variável. Os fungos en contrados geralmente são do gênero Penicillium, Monilla, Cladosporium, Micelia sterilia, Alternaria, Rhizopuz, Aspergillus, leveduras também são encontradas. Segundo os autores o agar extra to de malte é o meio de cultura mais favorável para o desen volvimento de linhagens de Penicillium isolados do iogurte.

Segundo SALINAS (1984b), leveduras são detectạ das (> 10 colōnias/g) em até 70\% de iogurte natural de 2 marcas da Espanha (50 amostras cada) analizados até 24 horas depois de produzidos; fungos também são encontrados. GREEN e IBE (1987) estudaram os contaminantes de iogurte produzido na Nigéria. Os autores sugerem que a alta contaminação encontrada é devido a um alto índice de contaminação inicial e uma refrigeração imprōpria do iogurte comercial. Foram encontradas, leveduras (contagem da ordem de $10^{4}-10^{6}$ u.f.c./ml), coliformes e estafilococos (10 
u.f.c./ml), fungos e psicotróficos $\left(10^{3}\right.$ u.f.c./ml). PREIXENS e SANCHO (1987), concluiram que o meio ácido do iogurte é desfavorável para o crescimento de coliformes, mas algumas linhagens de $E$. coli podem se adaptar a presença de ácido lático.

A contagem total de coliformes é menor que 10 u.f.c./ml de acordo com TAMINE et alli (1987).

De acordo com DIAZ et alli (1989), coliformes são detectadas em amostras de iogurte com menos de 48 horas e não durante o armazenamento. Leveduras sobrevivem em amostras com mais de 30 dias a temperaturas de armazenamento de $5-7^{\circ} \mathrm{C}$ e $11-13^{\circ} \mathrm{C}$. Fungos raramente sobrevivem por mais de 15 dias em iogurte natural.

Estudos realizados por SINHA et alli (1989), na microflora de iogurte comercial, não foram encontrados coliformes, fungos e leveduras quando estocados a 4,7 e $10^{\circ} \mathrm{C}$.

Segundo ROHM et alli (1990), dependendo da origem da amostra a população de leveduras aumenta de 10 u.f.c./g para $10^{6}$ u.f.c./g quando o iogurte é estocado a $10^{\circ} \mathrm{C}$. O meio de cultura utilizado para contagem de levedu ras é agar extrato de levedura glicose-clorofenicol (YGCA Merck), incubado a $25^{\circ} \mathrm{C}$ por 96 horas. 


\section{MATERIATS E MÉTODOS}

\section{Parte I: Anátises do iogurte comercial}

\section{Coleta das amostras}

As amostras de iogurte foram adquiridas no comércio da região de Piracicaba, SP, correspondentes a 4 diferentes marcas comerciais de iogurte natural e foram transportadas ao laboratório em recipientes com gelo, assegurando assim, a refrigeração às amostras. Para cada marca, foram coletadas 3 amostras com a mesma data de fabricacão. entre 7 a 15 dias de vida de prateleira, a cada mes e duran te 5 meses. As amostras foram apresentadas como A, B, C e D.

\section{Preparo das amostras}

As amostras foram mantidas sob refrigeração a $\pm 7^{\circ} \mathrm{C}$, até o momento da análise, o que foi sempre realiza do no mesmo dia da coleta. Os frascos foram abertos com assepsia e transferidos para um liquidificador esterilizado. 
A homogeneização foi feita tomando-se o cuidado de ligar e desligar 0 aparelho 3 vezes por 20 segundos com a finalidą de de padronização do processo, segundo FERREIRA e CHAVES (1981) .

\section{Acidez titulävel}

A acidez titulável das amostras foi determi nada através da titulação de $5 \mathrm{~g}$ de amostra com $\mathrm{NaOH} 0,1 \mathrm{~N}$, até o ponto de viragem do indicador fenolftaleína, segundo o LANARA (1981a).

Os resultados foram expressos em porcentagem de àcido lático.

\section{4. $\mathrm{pH}$}

A leitura dos valores de $\mathrm{pH}$ das amostras, foi realizada de acordo com o LANARA (1981a) utilizando-se para isso um potenciômetro, marca Digimed, devidamente calibrado.

\section{Peso Riquido}

O peso liquido foi determinado pesando-se ini cialmente os frascos com o produto e, posteriormente, as embalagens vazias, limpas e secas, de acordo com FERREIRA e Chaves (1981).

Os resultadós foram expressos em gramas. 


\section{Contagem de S. thermophilus e L. bulgaricus}

Para a contagem dessas bactérias, utilizouse o método de contagem em placas de Petri, com meio específico.

Foi realizada a contagem de unidades formadoras de colônias (u.f.c./ml) em meio TPPY - eriocromo-T agar, segundo BRACQUART (1981) e utilizando-se sobre-camada de meio nas placas de Petri.

Séries de diluições do iogurte foram feitas com solução estéril de triptona 0,1\%. Alíquotas de`0,1 ml de cada diluição foram utilizadas para semeadura por profundidade em placas de Petri contendo o meio diferencial. Logo após o endurecimento do meio de cultura sobrepunha-se uma outra camada do mesmo meio. As placas foram incubadas a $42^{\circ} \mathrm{C}$ em Jarra Gaspak, "sistema anaeróbico" por 48 horas e a contagem foi feita utilizando-se um contador do tipo Quebec.

\section{Contagem de coliformes totais}

Para esse grupo de microrganismos foi realizado a contagem de unidades formadoras de colônias (u.f. c./ml) em meio sólido, utilizando-se agar cristal violeta vermelho neutro Bile (VRBL - agar - Merck), através de semeadura por profundidade e incubação a uma temperatura de $32^{\circ} \mathrm{C}$ por 48 horas, tal como recomenda o LANARA (1981b). 


\section{Contagen de fungos e leveduras}

Para estes grupos foram feitas as contagens de unidades formadoras de colônias (u.f.c./ml) em BDA (Batata-dextrose-agar), preparado de acordo com o IANARA (1981b). Após a semeadura a incubação foi feita a uma temperatura de $32^{\circ} \mathrm{C}$ por 48 horas.

\section{Isolamento e purificação dos micronganismos láticos}

Inicialmente escolhia-se dentre as placas

contadas no item 6, aquelas que tivessem colônias dos dois microrganismos bem separadas. Estas colônias escolhidas eram inoculadas separadamente em leite desnatado reconstituído e esterilizado (12용 SNG) e incubadas a $42^{\circ} \mathrm{C}$ por 24 ho ras.

A seguir transferiu-se para TPPY - eriocromo-T agar por meio de estrias na superfície do meio sólido sobrepondo-se outra camada do mesmo meio. Incubou-se a $42{ }^{\circ} \mathrm{C}$ por 48 horas em Jarra Gaspak. Nesse meio, as colônias de L. bulgaricus apresentam-se transparentes, difusas (4 a $6 \mathrm{~mm}$ ) de forma indefinida e extremidade irregular. As colōnias de $S$. thermophilus apresentam-se circular, 1 a $3 \mathrm{~mm}$ de diâmetro, convexas, opacas, branco violeta, centro escuro.

As colônias características foram então transferidas novamente para leite esterilizado (12\% SNG) e 
incubadas a $42^{\circ} \mathrm{C}$ por 24 horas.

Fez-se coloração de gram, para se verificar

a pureza dos isolados.

Foi feita novamente a incubação em TPPY-erio cromo-T agar e então transferidos para leite esteriliżado (12\% SNG), adicionado de $1 \%$ de extrato de levedura DIFCO, para manutenção e testes de identificação. o isolamento das bactérias foi feito para todas as marcas de iogurte em estu do.

\section{Idertificação dos micronganismos}

\subsection{Identificação de L. bulgaricus}

Foram efetuadas provas de fermentação de açú cares em caldo MRS, utilizando-se os seguintes carboidratos: sacarose, ramnose, manitol, maltose, lactose, glicose e arabinose. Foram realizadas também provas de crescimento em caldo MRS contendo $2 \%$ e $4 \%$ de cloreto de sódio. Os testes com carboidratos e cloreto de sódio foram efetuados a $37^{\circ} \mathrm{C}$ por 7 dias, os quais foram realizados segundo MORAES e PASsos (1979).

\subsection{Identificação de S. thermophilus}

Foram efetuadas provas de crescimento a $45^{\circ} \mathrm{C}$ em caldo de levedura - glicose - extrato de carne, durante 48 horas. Conjuntamente, realizou-se fermentação de maltose em caldo MRS e crescimento em caldo MRS contendo $2 \%$ de clo- 
reto de sódio. Os testes do carboidrato e cloreto de sódio foram efetuados por 7 dias a $37^{\circ} \mathrm{C}$ de acordo com MORAEs e PASSOS (1979).

Parte 11: Crescimento populacional e produção de äcido pelos microrganismos isolados.

Nesta parte do trabalho foram utilizadas as culturas isoladas na parte I, item 9. Antes de se utilizar as culturas, estas foram submetidas a três repicagem suce $\underline{\underline{s}}$ sivas para reativação completa, em leite desnatado reconstituído, com 12\% SNG e esterilizado.

\section{Defirição da temperatura}

Atravēs da determinação da acidez titulável foram avaliadas as produções de ácido pelos microrganismos isolados, utilizando-se duas temperaturas, $37^{\circ} \mathrm{C}$ e $42^{\circ} \mathrm{C}$, em leite esterilizado (12\% SNG) e partindo-se sempre de um inóculo de $0,5 \%$ de cada uma das duas culturas reativadas e um tempo de desenvolvimento de 6 horas.

Neste ensaio, e em todos que se seguem o leite desnatado reconstituído com $12 \%$ de SNG, esterilizado foi inoculado com as culturas reativadas $(0,5 \%$ de $S$. thermophilus e $0,5 \%$ de L. bulgaricus) e depois transferidos assepticamente $\pm 40 \mathrm{ml}$, para tubos de ensaios de $12 \times 220 \mathrm{~mm}$ esterilizados, para que ocorresse o desenvolvimento. 


\section{Produsãon de ácido pelos pares estreptococo lactohacilo}

As culturas foram pareadas, um estreptosoco e um lactobacilo, em todas as combinacões possiveis considerando-se as diferentes marcas das amostras das quais elas se originaram.

Estes pares foram inoculados a $1 \%$ em leite esterilizado ( $12 \%$ SNG), na melhor temperatura, determinada no item anterior, por 6 horas e após este tempo foram realizadas análises de acidez titulável e pH. As análises foram realizadas em triplicatas, segundo ACCOLAs et alli (1977)

\section{Acidificação e pós-acidificacão}

De acordo com os resultados obtidos no tes te de produção de ácido pelos pares estreptococo-lactobaci10, foram selecionados os três pares melhores produtores de ácido para o estudo do desenvolvimento da acidez até a coagulação do leite e também após essa coagulação, durante a manutenção do produto em refrigerador.

Esses pares foram inoculados a $1 \%$ em leite esterilizado (12\% SNG) e incubados na melhor temperatura até a coagulação, com análise de acidez titulável e pH a cada hora. Após a coagulação, os iogurtes sofreram dois tra tamentos distintos:

Resfriamento lento: os frascos sairam da estufa e foram diretamento para o refrigerador a uma temperatura en- 
tre 7 e $10^{\circ} \mathrm{C}$

Resfriamento rápido: os frascos sairam da estufa e foram colocados rapidamente em um banho de gelo até atingirem a temperatura de $7^{\circ} \mathrm{C}$, então os frascos foram levados ao refrigerador a uma temperatura entre 7 e $10^{\circ} \mathrm{C}$.

Para os dois tratamentos, os frascos ficaram no refrigerador por 30 dias, para o estudo da pós-acidifica ção através da análise da acidez titulável e pH nos tempos $0,6,12,18$ e 24 horas e, a seguir, de 48 em 48 horas até completar 30 dias. O tempo do resfriamento, corresponde ao momento em que os frascos são colocados no refrigerador.

\section{Crescimento do L. bulgaricus e S. thermophilus}

Foram realizadas contagem de unidades formadoras de colônias (u.f.c./ml) em meio TPPY-eriocromo-T agar, de acordo com BRACQUART (1981), e essa contagem foi realiza da de hora em hora, até a coagulação. Após isso, no periodo de pós-acidificação no refrigerador, a contagem foi realiza da nos tempos $0,6,12,18$ e 24 horas e depois, de 48 em 48 horas, até atingir os 30 dias, segundo ACCOLAs et alli (1977).

As análises foram sempre realizadas em triplicatas e os experimentos em duplicatas. 


\section{RESULTADOS E DISCUSSAO}

1. Peso Riquido, acidez titulävel e pH dos iogurtes adquiridos no comércio.

Os valores médios observados para o peso líquido, acidez titulável e pH nas amostras de iogurte adquiridas no comércio encontram-se expressos na tabela 1.

o valor para o peso líquido, declarado nas embalagens, é de 200,0 gramas e pelos valores apresentados na tabela 1 constata-se que o iogurte $\mathrm{C}$ apresentou sempre valores abaixo do declarado, com um peso líquido médio de 194,8g para as análises dos cinco meses, ou seja, 2,58\% menos iogurte do que o declarado. O iogurte B, por outro lado, apresentou em très meses valores superiores ao declarado e nos outros dois meses valores ligeiramente infériores, resultando em um valor médio, para os cinco meses, 0,32\% aci ma do declarado na embalagem. Os iogurtes. A e D apresentaram em um mês, cada um deles, peso líquido superior ao declarado enquanto que nos outros meses os valores estiveram um pouco abaixo desse, o que resultou em pesos médios para 


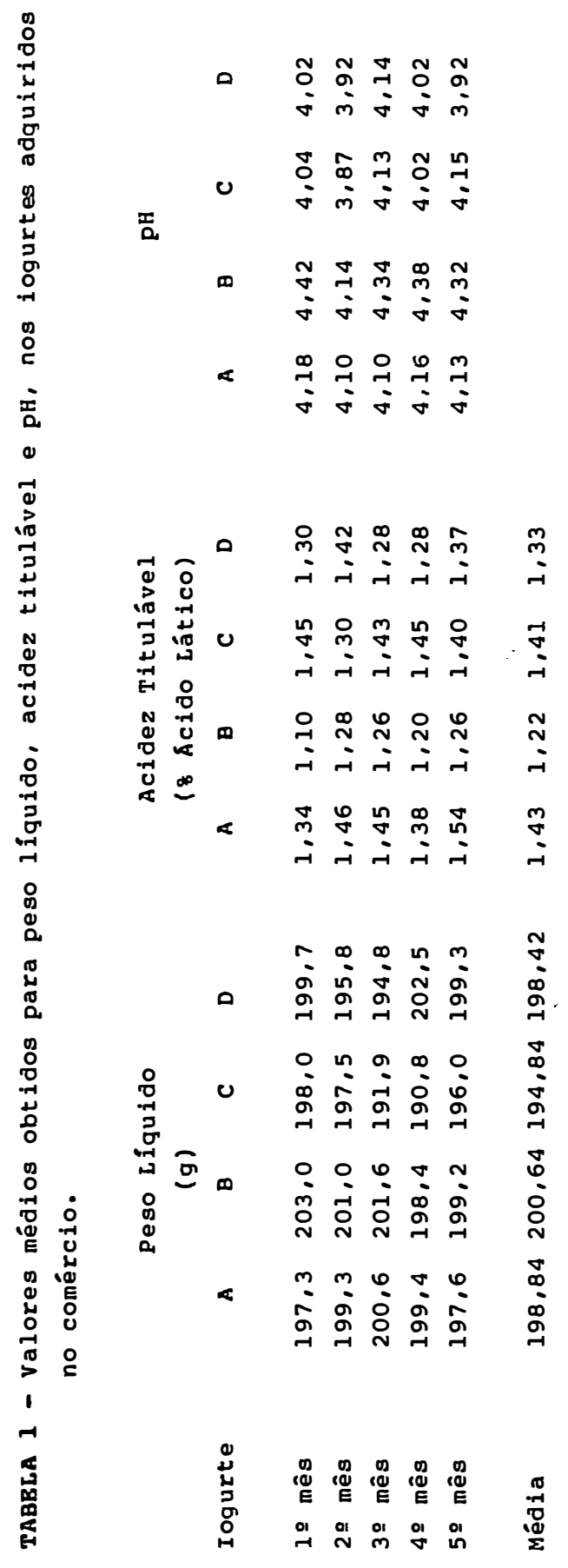


os cinco meses, respectivamente, 0,58 e 0,79\% abaixo das du zentas gramas declaradas nas embalagens.

Para todos os iogurtes avaliados verifica-se uma variação, em relação ao peso indicado na embalagem, de $-4,6 \%$ (iogurte $C, 40$ mes) a $+1,5 \%$ (iogurte $B, 10$ mes). Além da variação negativa ser bem maior que a positiva, nota-se que $75 \%$ dos valores estão abaixo do peso declarado na embalagem.

Esses resultados contrastam bastante com aqueles obtidos por RICHMOND et alli (1979) para a região de Michigam, EUA, onde apenas 10,6\% das amostras apresentaram peso líquido abaixo do valor indicado na embalagem e a variação verificada foi de $-1,5 \%$ 웅 $+12,6 \%$. Também apresentam um quadro bem distinto daquele encontrado por FERREIRA e CHAVES (1981) para cinco meses de amostragens em iogurtes comercializados na Zona da Mata, MG, quando apenas um tipo dos oito avaliados, apresentou resultado médio abaixo do pe so declarado: interessante lembrar que, provavelmente, as marcas comercializadas em Minas Gerais não devem diferir muito das comercializadas em Piracicaba.

Os valores médios obtidos para a acidez titü lável e pH dos iogurtes amostrados, constantes da tabela 1 , mostram que o iogurte B apresentou os menores indices de acidez e, consequentemente, os maiores valores de $\mathrm{pH}$ dentre as amostras analisadas enquanto os iogurtes A e C apresenta ram maior acidez, com valores mais baixos de $\mathrm{pH}$. 
Segundo FERREIRA e CHAVES (1981) um certo grau de acidez é desejável no iogurte, porém, superacidificação leva à separaçao do sôro e deterioração de sua con sistēncia e viscosidade. ROBINSON e TAMINE (1976) sugerem uma acidez de 0,72 a 1,17\% ácido lático para o iogurte e, dentro desse intervalo situa-se a grande maioria dos valores encontrados ou recomendados por diferentes pesquisadores. Os valores encontrados para os iogurtes analisados nes te trabalho mostram que apenas o iogurte $B$ poder-se-ia enquadrar nesses valores enquanto os demais apresentam acidez superior sem, entretanto, apresentarem valores tão elevados quanto aos encontrados por FERREIRA e CHAVES(1981) para os iogurtes comercializados na Zona de Mata, MG.

2. Contagens de L. bulgaricus, S. thermophilus, coliformes, fungos e leveduras para os iogurtes adquiridos no conércio.

Na tabela 2 encontram-se os valores médios ob tidos para as contagens de L. bulgaricus, S. thermophilus, coli formes, fungos e leveduras e também as relações bastonete:cocos, para as amostras analisadas.

Os resultados obtidos para as contagens das bactérias láticas nos iogurtes A, C e C estão de acordo com os resultados relatados por DAVIS(1975), GREEN e IBE(1987) e ROHM et alli(1990). Para o iogurte D, nos três, primeiros meses de amostragem, não foram detectados $L$. bulgaricus e S. thermophilus viáveis no produto, comprometen- 


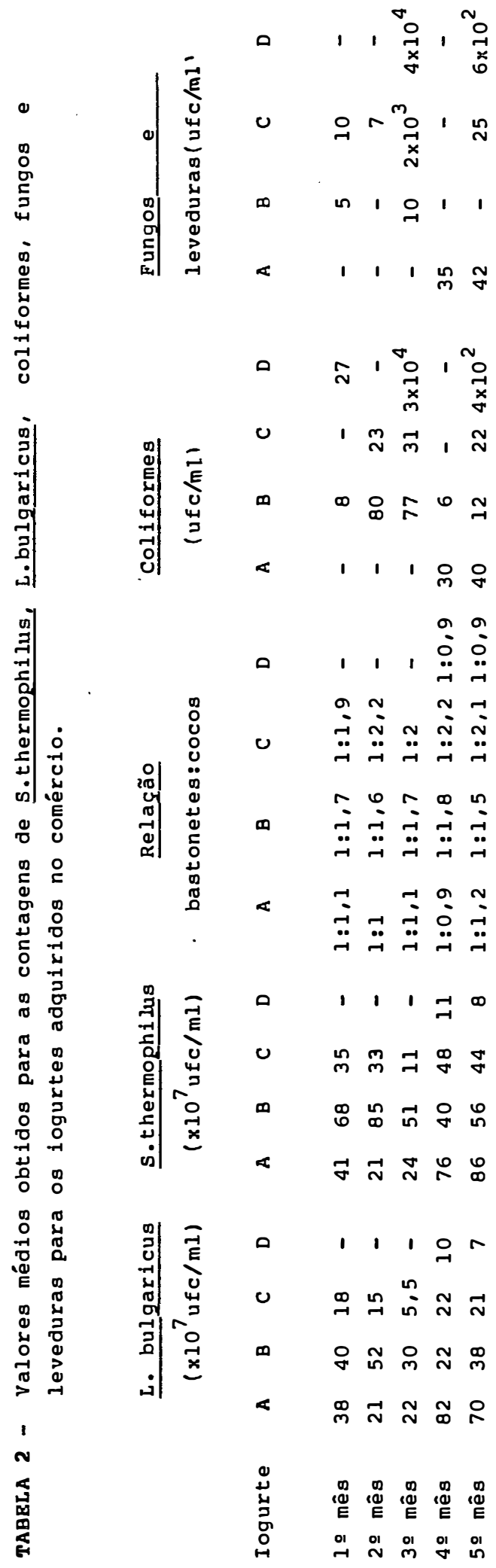


do a qualidade natural desse iogurte, podendo inclusive, su gerir que algum tratamento não recomendado foi utilizado pa ra destruição dessas bactérias. Nos outros dois meses, embo ra se detectasse a presença de bactérias láticas viáveis nas amostras do iogurte D, os valores foram acentuadamente infe riores aos obtidos para as outras marcas.

Uma relação bastonetes:cocos de $1: 1$ é geralmente citada pela maioria dos pesquisadores como ideal para que o iogurte apresente as melhores qualidades organolépticas(ACCOLAS et alli, 1977; LEE et alli, 1974; LABRAPOUJ_OS et alli, 1982; HAMANN e MARTH, 1984 e outros). Observandose os resultados expressos na tabela 2 nota-se que dentre os iogurtes comerciais analisados apenas os da marca A apresen tam relação bastonetes:cocos muito próxima daquela citada cô mo ideal, o mesmo ocorrendo para as amostras da marca D no 4o e 50 mes, já os iogurtes das marcas B eC apresentaram nū mero de cocos bem maior que o de bastonetes entretanto estes resultados estão de acordo com os encontrados por DEMETER (1969) e RADKE-MITCHELL e SANDINE (1986).

As contagens para coliformes, fungos e leveduras, nos iogurtes amostrados (tabela 2) revelaram que a marca A nos très primeiros meses, a marca C no 40 mês e a marcad no 20 mès e 40 mês não apresentaram nenhum desses contaminantes. Coliformes, quando presentes, em 9 amostras (45\% do total) superou o número de 10 u.f.c./ml encontrado por GREEN e IBE(1987) e também TAMINE et alli(1987). As con 
tagens para leveduras e fungos revelaram, pelo menos, três valores bastante elevados (amostra C, 30 mês e amostra D, 30 e 50 meses) praticamente igualando ou superando os valo res mais elevados, $10^{3}$ células por grama, encontrados na literatura (SURIYARACHCHI e FLEET, 1981).

\section{Identificação dos L. bulgaricus}

As culturas puras provenientes da colônias separadas no meio diferencial e consideradas L. bulgaricus, foram submetidas a uma série de provas de fermentação de diferentes carboidratos e provas de crescimento em meio a 2 e 4\% de cloreto de sódio.

Os resultados obtidos para as quatro cultu ras bem como as características do L. bulgaricus, conforme MORAES e PASSOS (1979), encontram-se na tabela 3. Verifica-se pelos resultados que as quatro culturas testadas eram realmente L. bulgaricus.

\section{Identificação dos S. thermophilus}

As culturas puras provenientes das colônias separadas no meio diferencial e consideradas $S$. thermophilus foram submetidas a provas de fermentação da maltose e de crescimento a $45^{\circ} \mathrm{C}$ em meio a $4 \%$ de cloreto de sódio e os resultados encontram-se na tabela 4 juntamente com as caracteristicas do $S$. thermophilus conforme MORAES e PASSOS (1979). Os resultados obtidos confirmaram tratar-se realmen te de S. thermophilus. 
Tabela 3 - Identificação do L. bulgaricus

\begin{tabular}{lccccc}
\hline & \multicolumn{5}{c}{ L. bulgaricus } \\
\cline { 2 - 6 } & A & B & C & D & $\begin{array}{c}\text { MORAES e PAS- } \\
\text { SOS (1979) }\end{array}$ \\
\cline { 2 - 6 } NaCl 4\% & - & - & - & - & - \\
NaCl 2\% & + & + & + & + & - \\
Sacarose & - & - & - & - & - \\
Ramnose & - & - & - & - & - \\
Manitol & - & - & - & - & + \\
Maltose & - & - & - & - & + \\
Lactose & + & + & + & + & - \\
Glicose & + & + & + & + & - \\
Arabinose & - & - & - & - & + \\
\hline
\end{tabular}

Tabela 4 - Identificação do S. thermophilus

\begin{tabular}{|c|c|c|c|c|}
\hline $\mathrm{A}$ & B & $c$ & $\mathrm{D}$ & $\begin{array}{l}\text { MORAES } \text { e PAS- } \\
\text { SOS }(1979)\end{array}$ \\
\hline
\end{tabular}

Crescimento a $45^{\circ} \mathrm{C}$

Fermentação de mal tose

Crescimento em $\mathrm{NaCl}$ a 2\%

$\begin{array}{lll}+ & + & + \\ - & - & - \\ - & - & -\end{array}$

5. Produção de ácido pelos $L_{0}$ bulgaricus e S. thernophilus isolados. 
thermophilus e L. bulgaricus isoladas dos iogurtes comerciais, expresso pelos valores da acidez titulável obtida após 6 horas de incubação em leite desnatado (12\% SNG) esteriliza do, encontram-se na tabela 5 .

Tabela 5 - Desenvolvimento da acidez titulável (\% ac. lático) a $37^{\circ} \mathrm{C}$ e $42^{\circ} \mathrm{C}$ pelas culturas isoladas.

\begin{tabular}{lcccc}
\hline & \multicolumn{2}{c}{ L. bulgaricus } & \multicolumn{2}{c}{ S. thermophilus } \\
& $37^{\circ} \mathrm{C}$ & $42^{\circ} \mathrm{C}$ & $37^{\circ} \mathrm{C}$ & $42^{\circ} \mathrm{C}$ \\
Iogurte A & 0,46 & 0,65 & 0,17 & 0,21 \\
Iogurte B & 0,24 & 0,50 & 0,16 & 0,17 \\
Iogurte C & 0,38 & 0,72 & 0,16 & 0,18 \\
Iogurte D & 0,36 & 0,48 & 0,17 & 0,17 \\
\hline
\end{tabular}

As quatro culturas de $S$. thermophilus comporta ram-se de modo bastante semelhante quanto ao desenvolvimento da acidez, tanto a $37^{\circ} \mathrm{C}$ como a $42^{\circ} \mathrm{C}$, e essas produções foram bastante inferiores àquelas apresentadas pelos L. bulgaricus os quais, por sua vez, apresentaram variações bem maiores na acidez produzida pelas diferentes culturas.

Quanto às temperaturas, nota-se pelos resultạ dos obtidos que a acidez foi mais elevada a $42^{\circ} \mathrm{C}$ que a $37^{\circ} \mathrm{C}$ em todos os casos e, por esse motivo, em todos os experimentos subsequentes neste trabalho, a temperatura de $42^{\circ} \mathrm{C}$ foi a utilizada. Maiores variações no desenvolvimento da acidez entre diferentes culturas de L. bulgaricus quando comparadas 
com as variações entre culturas de $S$. thermophilus também foram observadas por ACCOLAS et alli. Esses autores também verificaram que tanto $L$. bulgaricus como $S$. thermophilus produzem mais acidez a $42^{\circ} \mathrm{C}$ que a $37^{\circ} \mathrm{C}$.

\section{Produção de acidez pelos pares estreptococos-lactobacilos}

Na tabela 6 são apresentados os resultados obtidos para acidez titulável e pH desenvolvidos pelas cul turas mistas (1 estreptococo e 1 lactobacilo) incubadas a $42^{\circ} \mathrm{C}$ por 6 horas, em leite desnatado (12\% SNG) e esterili zado. Nessa tabela aparecem também os resultados da' soma da acidez produzida pelas culturas simples (tabela 5), que compõe cada par estudado.

Ao avaliar-se as produções de ácido pelas culturas mistas comparando-as com os resultados da tabela 5, verifica-se que as culturas mistas produziram notadamen te mais ácido que qualquer uma de suas duas culturas compo nentes, quando consideradas isoladamente. Entretanto, quan do se compara a soma da acidez das culturas simples, e aci dez de cultura mista correspondentes, constata-se que para duas culturas mistas (LASD e LDSC) esses valores são iguais, enquanto que para quatro culturas mistas (LCSA, LCSD, LDSA e LDSD) houve maior produção de ácido quando as culturas estavam juntas. Esses resultados são comparáveis aos obtidos por ACCOLLAS et alli (1977).

Observando-se ainda a produção total de áci 
Tabela 6 - Desenvolvimento da acidez titulável e pH pelas culturas mistas, a $42^{\circ} \mathrm{C}$.

$\begin{array}{lcc}\begin{array}{l}\text { Cultura } \\ \text { Mista }\end{array} & \begin{array}{c}\text { Acidez Titulável } \\ \text { (\%ac. lático) }\end{array} & \begin{array}{c}\text { Soma acidez } \\ \text { Culturas Simples }\end{array} \\ \text { LASA } & 0,70 & 0,86 \\ \text { LASB } & 0,48 & 0,82 \\ \text { LASC } & 0,54 & 0,83 \\ \text { LASD } & 0,82 & 0,82 \\ \text { LBSA } & 0,70 & 0,71 \\ \text { LBSB } & 0,37 & 0,67 \\ \text { LBSC } & 0,35 & 0,68 \\ \text { LBSD } & 0,60 & 0,67 \\ \text { LCSA } & 1,03 & 0,93 \\ \text { LCSB } & 0,78 & 0,89 \\ \text { LCSC } & 0,80 & 0,90 \\ \text { LCSD } & 1,10 & 0,89 \\ \text { LDSA } & 0,78 & 0,63 \\ \text { LDSB } & 0,54 & 0,59 \\ \text { LDSC } & 0,60 & 0,60 \\ \text { LDSD } & 0,79 & 0,59 \\ & & \\ \text { L - Lactobacillus bulgaricus } & \\ \text { S - Streptococcus thermophilus } & \\ \text { A, B, C, D - marcas do iogurte de origem da cultura. }\end{array}$

do pelas culturas mistas, e tomando-se como referência o va lor arbitrário, sugerido por MARTINS e LUCHESE (1988), de $0,70 \%$ de ácido lático como valor mínimo de acidez a sẹr atingido pela cultura mista para ser aproveitada industrial mente, constata-se que nove, dos vinte pares testados neste trabalho, igualaram ou ultrapassaram esse mínimo. Desses 
pares, foram selecionados os pares LCSD, LCSA e LASD para estudos posteriores de acidificação e pós-acidificação , por terem se mostrado os melhores produtores de ácido , neste experimento.

7. Desenvolvimento da acidez desrante o periodo de incubação laci difícação) e de armazenamento (pós-acidificação), para os três pores de culturas selecionadas.

$$
\text { Os valores de acidez titulável expressos }
$$
em porcentagem de ácido lático e pH das três culturas mis tas incubadas durante $4 \mathrm{~h}$ a $42^{\circ} \mathrm{C}$ em leite desnatado (12\% SNG) esterilizado, encontra-se na tabela 7 .

Tabela 7 - Desenvolvimento da acidez titulável e pH durante o periodo de incubação a $42^{\circ} \mathrm{C}$.

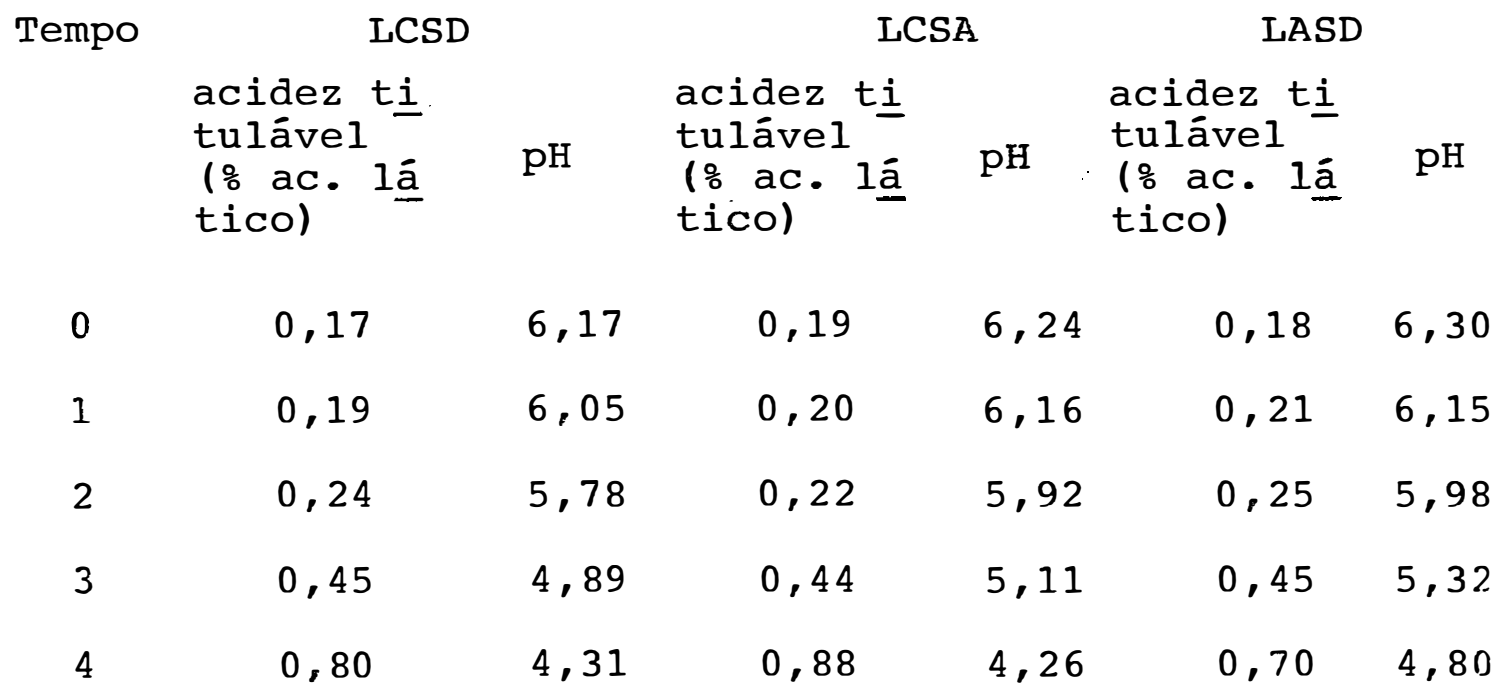

Verifica-se, pelos resultados obtidos, que a variação na acidez e pH para os três pares testados comportou-se de modo semelhante, com variação discreta nas duas 
primeiras horas e variação acentuada nas duas últimas horas de incubação.

Os resultados obtidos para acidez titulável ( $\%$ de ácido lático) e pH após a transferência dos iogurtes para o refrigerador, com e sem resfriamento em banho de ge lo (resfriamento rápido e resfriamento lento), encontra-se na tabela 8 .

Pelos valores apresentados nessa tabela, no ta-se que o resfriamento rápido retarda bastante o desenvolvimento da pós-acidificação, principalmente para os iogurtes LCSD e LCSA que, com resfriamento lento, apos 11 dias (264 horas) já haviam atingido uma acidez comparável à apresentada após 1 mês (744 horas), quando submetidos ao resfriamento rápido.

No início do período de armazenamento, ○ iogurte LCSD apresentou o menor valor para a acidez titulá vel $(0,70 \%)$, dentre os três iogurtes testados, mas, duran te o armazenamento foi o que apresentou desenvolvimento de acidez mais acentuado, com um valor final de acidez titulá vel de $1,71 \%$ quando se utiliza resfriamento lento e $1,52 \%$ quando o resfriamento foi rápido, valores esses, superiores aos dos outros dois iogurtes. Por outro lado, o iogurte LASD no inicio do armazenamento, apresentava acidez titulável de $0,80 \%$, acidez essa superior à do iogurte LCSD , porém por apresentar uma pós-acidificação menos acentuada, os valores de acidez final foram os mais baixos 


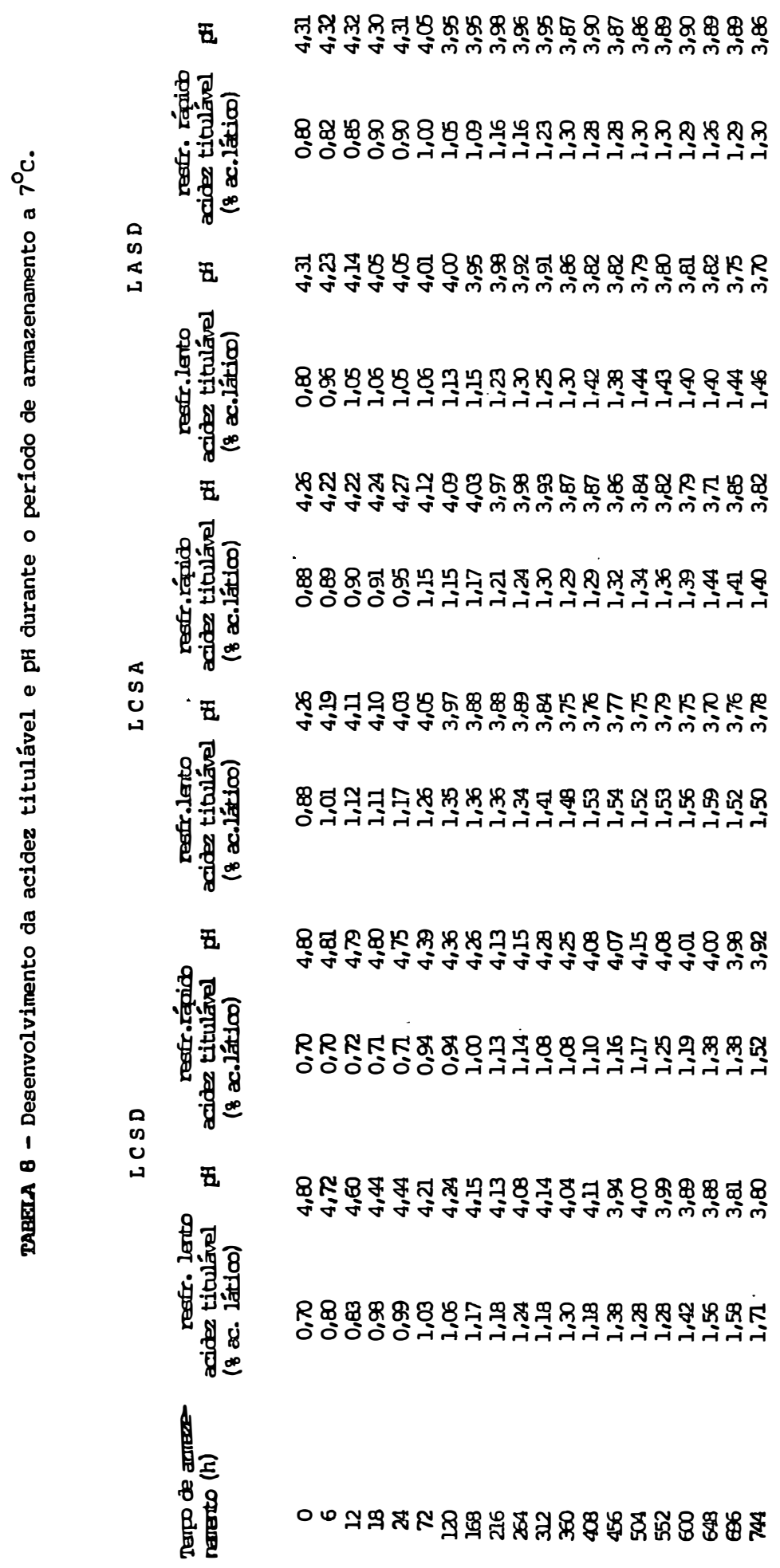


dentre os três iogurtes testados.

O desenvolvimento da acidez para os três iogurtes testados, comportou-se de forma semelhante à relatada por JORDANO et alli (1988), que verificaram um desenvolvimento de acidez mais acentuado durante os primeiros onze dias, que entre onze e vinte e um dias de armazenamento.

Os valores finais de acidez, tanto para o io gurte com resfriamento lento, como para o resfriamento rápi do, estão bem ackima dos valores 1,0 e $1,25 \%$ recomendados por HUMPHREY e PLUNKETT (1969) e 0,72 a 1,17\% conforme ROBINSON e TAMINE (1976). Entretanto, os valores obtidos neste trabalho são condizentes com aqueles apresentados por TERRA et alli (1977) que analisaram três marcas de iogurte comercializado em Santa Maria, RS, encontrando para duas marcas, acidez sempre acima ḍe 1,20\% de ácido lático, e sèndo que, 30,76 e 46,15\% das amostras dessas marcas apresenta ram acidez acima de 1,40\% de ácido lático.

Os valores de $\mathrm{pH}$ observados ao final do período de armazenamento estão dentro dos limites apresentados por DUITSCHEVER et alli (1972) de 3,27 a 4,53 e DAVIS e MCLACHLAN (1970) de 3,7 a 4,0, porém, inferiores ao valor de 4,0 citado por SELLARS e BABEL (1970), de 4,23 por RICHMOND et alli (1979) e 4,4 por SINHA et alli (1989). Com exceção do iogurte LCSD com resfriamento rápido, os demais apresentaram pH abaixo dos limites observados por LUtCK e MOSTERT (1971) de 3,9 a 4,1. 


\section{Nümero de lactobacilos e estreptococos nos iogurtes durante o periodo de incubasão e o periodo de armazenamento.}

Nas tabelas 9, 10 e 11 são apresentados os va lores encontrados para as contagens de L. bulgaricus e de S. thermophilus nos iogurtes LCSD, LCSA e LASD bem Como, as re lações bastonetes:cocos em cada caso.

Verifica-se, pelos resultados obtidos para os três iogurtes, que tanto o número de L. bulgaricus como o de S. thermophilus aumentaram durante o transcorrer do periodo de incubação, sendo esse aumento bem mais significativo para S. thermophilus, tanto assim que a relação bastonetes:cocos que no início estava praticamente em 1:1, com três horas de incu bação apresentou três vezes mais cocos que bastonetes, com relações bastonetes:cocos de $1: 3,2 ; 1: 3,1$ e 1:3,2 para os iogurtes LCSD, LCSA e LASD, respectivamente. Após a terceira hora de incubação, embora o número de bactérias continuasse a crescer, estreptococos apresentaram um aumento populacional mais lento e aquelas relações bastonetes:cocos baixaram para $1: 2,5 ; 1: 2,4$ e $1: 2,5$, respectivamente.

Esse crescimento mais rápido dos S. thermophilus no início da acidificação, está de acordo com a afirmação de TAMINE e DEETH (1980), de que há inicialmente uma producão de aminoácidos essenciais pelos lactobacilos que estimulam o crescimento rápido dos estreptococos e estes, produzindo ácí do lático, acidificam o meio tornando-o favorável ao cresci- 
TABFIA 9 - Número de lactobacilos e estreptococos no iogurte LCSD duran te o período de incubação e o período de armazenamențo.

I N C U B A Ç $\nwarrow$ O

\begin{tabular}{|c|c|c|c|}
\hline Tempo(h) & L.bulgaricus & S.thermophilus & $\begin{array}{c}\text { Relação } \\
\text { bastonetes:cocios }\end{array}$ \\
\hline $\begin{array}{l}0 \\
1 \\
2 \\
3 \\
4\end{array}$ & $\begin{array}{l}46 \cdot 10_{5}^{5} \\
89 \cdot 10_{6} \\
48 \cdot 10^{6} \\
78 \cdot 10_{7} \\
38 \cdot 10^{7}\end{array}$ & $\begin{array}{r}48 \cdot 10_{5}^{5} \\
201 \cdot 10_{6}^{5} \\
123 \cdot 10_{6}^{6} \\
247 \cdot 10_{7} \\
96 \cdot 10^{6}\end{array}$ & $\begin{array}{l}1: 1 \\
1: 2,3 \\
1: 2,6 \\
1: 3,2 \\
1: 2,5\end{array}$ \\
\hline
\end{tabular}

A R M Z E N A M N T O

\begin{tabular}{rrrrrrr} 
& \multicolumn{2}{c}{ Resfriamento } & \multicolumn{2}{c}{ Resfriamento } & \multicolumn{2}{c}{ Resfriamento } \\
& Lento & Rápido & Lento & Rápido & Lento & Rápido \\
& $\left(x 10^{7}\right)$ & $\left(x 10^{7}\right)$ & $\left(x 10^{7}\right)$ & $\left(x 10^{7}\right)$ & & \\
0 & 38 & 38 & 96 & 96 & $1: 2,5$ & $1: 2,5$ \\
6 & 52 & 41 & 100 & 86 & $1: 1,9$ & $1: 2,1$ \\
12 & 81 & 74 & 98 & 89 & $1: 1,2$ & $1: 1,2$ \\
18 & 100 & 94 & 112 & 100 & $1: 1,1$ & $1: 1,1$ \\
24 & 104 & 100 & 109 & 101 & $1: 1$ & $1: 1$ \\
72 & 98 & 102 & 96 & 99 & $1: 1$ & $1: 1$ \\
120 & 73 & 49 & 54 & 49 & $1: 0,7$ & $1: 1$ \\
168 & 88 & 81 & 80 & 74 & $1: 0,9$ & $1: 0,9$ \\
216 & 101 & 100 & 95 & 98 & $1: 0,9$ & $1: 1$ \\
264 & 95 & 102 & 99 & 102 & $1: 1$ & $1: 1$ \\
312 & 94 & 49 & 98 & 59 & $1: 1$ & $1: 1,2$ \\
360 & 47 & 48 & 51 & 48 & $1: 1,1$ & $1: 1$ \\
408 & 45 & 40 & 45 & 40 & $1: 1$ & $1: 1$ \\
456 & 30 & 30 & 30 & 30 & $1: 1$ & $1: 1$ \\
504 & 11 & 10 & 11 & 10 & $1: 1$ & $1: 1$ \\
552 & 8 & 8 & 8 & 8 & $1: 1$ & $1: 1$ \\
600 & 6 & 5 & 6 & 7 & $1: 1$ & $1: 1,4$ \\
648 & 3 & 3 & 5 & 5 & $1: 1,6$ & $1: 1,6$ \\
696 & 4 & 3 & 3 & 3 & $1: 0,8$ & $1: 1$ \\
744 & 2 & 2 & 3 & 3 & $1: 1,5$ & $1: 1,5$
\end{tabular}


TABRI.A 10 - Número de lactobacilos e estreptococos no iogurte LCSA durante o período de incubação e o período de armazenamento.

I N C U B A Ç $\AA 0$

\begin{tabular}{|c|c|c|c|}
\hline Tempo $(h)$ & L. bulgaricus & S. thermophilus & $\begin{array}{c}\text { Relação } \\
\text { bastonetes:cocos }\end{array}$ \\
\hline $\begin{array}{l}0 \\
1 \\
2 \\
3 \\
4\end{array}$ & $\begin{array}{l}45: 10^{4} \\
61: 10^{4} \\
18: 10^{6} \\
28: 10^{6} \\
15: 10^{2}\end{array}$ & $\begin{array}{l}39 \cdot 10^{4} \\
82 \cdot 10_{5} \\
34 \cdot 10^{6} \\
87: 10^{7} \\
36 \cdot 10^{2}\end{array}$ & $\begin{array}{l}1: 0,9 \\
1: 1,3 \\
1: 1,9 \\
1: 3,1 \\
1: 2,4\end{array}$ \\
\hline
\end{tabular}

A R M Z E N A ENTO

\begin{tabular}{|c|c|c|c|c|c|}
\hline \multicolumn{2}{|c|}{ Resfriamento } & \multicolumn{2}{|c|}{ Resfriamento } & \multicolumn{2}{|c|}{ Resfriamento } \\
\hline $\begin{array}{l}\text { lento } \\
\left(\times 10^{7}\right)\end{array}$ & $\begin{array}{l}\text { rápido } \\
\left(x 10^{7}\right)\end{array}$ & $\begin{array}{l}\text { lento } \\
\left(x 10^{7}\right)\end{array}$ & $\begin{array}{l}\text { rápido } \\
\left(x 10^{7}\right)\end{array}$ & lento & rápido \\
\hline 15 & 15 & 36 & 36 & $1: 2,4$ & $1: 2,4$ \\
\hline 95 & 90 & 141 & 121 & $1: 1,5$ & $1: 1,4$ \\
\hline 108 & 101 & 140 & 122 & $1: 1,3$ & $1: 1,2$ \\
\hline 148 & 98 & 151 & 121 & $1: 1$ & $1: 1,2$ \\
\hline 158 & 140 & 169 & 145 & $1: 1,1$ & $1: 1$ \\
\hline 148 & 122 & 150 & 126 & $1: 1$ & $1: 1$ \\
\hline 87 & 86 & 93 & 84 & $1: 1,1$ & $1: 1$ \\
\hline 65 & 59 & 69 & 56 & $1: 1,1$ & $1: 0,9$ \\
\hline 58 & 53 & 56 & 50 & $1: 1,1$ & $1: 0,9$ \\
\hline 56 & 51 & 52 & 46 & $1: 0,9$ & $1: 0,9$ \\
\hline 48 & 55 & 48 & 51 & $1: 1$ & $1: 0,9$ \\
\hline 48 & 42 & 50 & 40 & $1: 1$ & $1: 1$ \\
\hline 19 & 25 & 21 & 20 & $1: 1,1$ & $1: 0,8$ \\
\hline 40 & 36 & 40 & 36 & $1: 1$ & $1: 1$ \\
\hline 21 & 20 & 22 & 20 & $1: 1$ & $1: 1$ \\
\hline 15 & 17 & 15 & 17 & $1: 1$ & $1: 1$ \\
\hline 12 & 14 & 13 & 15 & $1: 1,1$ & $1: 1,1$ \\
\hline 9 & 9 & 8 & 9 & $1: 0,9$ & $1: 1$ \\
\hline 2 & 4 & 2 & 3 & $1: 1$ & $1: 0,8$ \\
\hline 3 & 5 & 2 & 4 & $1: 07$ & $1: 0,8$ \\
\hline
\end{tabular}


TABELA 11 - Número de lactobacilos e estreptocos no iogurte LASD durante o período de incubação e o período de armazenamento.

I N C U B A Ç $\AA$ O

\begin{tabular}{|c|c|c|c|}
\hline Termpo (h) & L.bulgaricus & S.thermophilus & $\begin{array}{l}\text { Relação } \\
\text { bastonetes:cocos }\end{array}$ \\
\hline $\begin{array}{l}0 \\
1 \\
2 \\
3 \\
4\end{array}$ & $\begin{array}{l}15 \cdot 10_{5}^{5} \\
34 \cdot 10_{6}^{6} \\
42 \cdot 10_{7} \\
35 \cdot 10_{7} \\
48 \cdot 10^{2}\end{array}$ & $\begin{array}{r}14 \cdot 10_{5}^{5} \\
60 \cdot 10_{6}^{5} \\
88 \cdot 10_{7}^{6} \\
112 \cdot 10_{7} \\
120 \cdot 10^{7}\end{array}$ & $\begin{array}{l}1: 0,9 \\
1: 1,8 \\
1: 2,1 \\
1: 3,2 \\
1: 2,5\end{array}$ \\
\hline
\end{tabular}

A R M Z ENAMENTO

\begin{tabular}{ccccc}
\multicolumn{2}{c}{ Resfriamento } & \multicolumn{2}{c}{ Resfriamento } & \multicolumn{2}{c}{ Resfriamento } \\
lento & rápido & lento & rápido & lento rápido \\
$\left(x 10^{7}\right)$ & $\left(x 10^{7}\right)$ & $\left(x 10^{7}\right)$ & $\left(x 10^{7}\right)$ &
\end{tabular}

$\begin{array}{rrrrrll}0 & 48 & 48 & 120 & 120 & 1: 2,5 & 1: 2,5 \\ 6 & 68 & 62 & 127 & 120 & 1: 1,9 & 1: 1,9 \\ 12 & 130 & 120 & 206 & 192 & 1: 1,6 & 1: 1,6 \\ 18 & 131 & 124 & 151 & 142 & 1: 1,2 & 1: 1,1 \\ 24 & 118 & 101 & 120 & 108 & 1: 1 & 1: 1,1 \\ 72 & 109 & 92 & 102 & 96 & 1: 0,9 & 1: 1 \\ 120 & 81 & 65 & 78 & 63 & 1: 1 & 1: 1 \\ 168 & 189 & 59 & 192 & 52 & 1: 1 & 1: 0,9 \\ 216 & 64 & 58 & 66 & 54 & 1: 1 & 1: 0,9 \\ 264 & 79 & 41 & 73 & 47 & 1: 0,9 & 1: 1,1 \\ 312 & 72 & 68 & 68 & 68 & 1: 0,9 & 1: 1 \\ 360 & 71 & 69 & 72 & 62 & 1: 1 & 1: 0,9 \\ 408 & 70 & 69 & 71 & 70 & 1: 1 & 1: 1 \\ 456 & 64 & 56 & 60 & 58 & 1: 0,9 & 1: 1 \\ 504 & 54 & 42 & 52 & 40 & 1: 1 & 1: 1 \\ 552 & 48 & 36 & 50 & 35 & 1: 1 & 1: 1 \\ 600 & 50 & 36 & 56 & 34 & 1: 1,1 & 1: 0,9 \\ 648 & 2 & 3 & 1 & 3 & 1: 0,5 & 1: 1 \\ 696 & 4 & 15 & 4 & 17 & 1: 1 & 1: 1,1 \\ 744 & 4 & 4 & 2 & 3 & 1: 0,5 & 1: 0,8\end{array}$


mento dos lactobacilos, além de produzirem ácido fórmico que estimulam o crescimento do L. bulgaricus. A proporção de 1 lactobacilo: 3 estreptococos na primeira fase e a predomi nância de lactobacilos a seguir, também foram observadas por DAVIS (1975) e SURAYARACHCHI e FLEET (1981).

Pelos resultados obtidos durante o período de armazenamento, nota-se que o número de microrganismos con tinuou a aumentar nas primeiras 18 a 24 horas e, a partir desse primeiro dia de armazenamento, as contagens revelaram uma nítida tendência de redução nos números de lactobacilos e de estreptococos.

A relação bastonetes:cocos apresentou uma predominância decrescente de cocos durante as primeiras 24 horas de armazenamento e a partir desse tempo, para os três iogurtes testados, houve uma situação de equilíbrio entre as duas espécies de bactérias láticas, mantendo-se a relação aproximadamente de 1:1.

Comportamento idêntico ao observado neste trabalho, com um crescimento populacional logo após a fabricação diminuindo posteriormente durante a armazenagem também foi relatado por HAMANN e MARTH (1984). 


\section{CONCLUSÕES}

1. Os resultados obtidos demonstraram existência de iogurtes comerciais com peso líquido abaixo do declarado na embalagem. 2. Constatou-se existência de iogurtes comerciais colocados à disposição do consumidor, com total ausência de bactérias láticas vivas.

3. Elevado número de coliformes, tal como $3 \times 10^{4} \mathrm{u} . \mathrm{f} . \mathrm{c} . / \mathrm{ml}$ e de fungos e leveduras, como $4 \times 10^{3} \mathrm{u} . \mathrm{f} . \mathrm{c} . / \mathrm{ml}$ foram encontrados em iogurtes adquiridos no comércio de Piracicaba.

4. As culturas mistas ativas nos iogurtes comerciais amostra dos compunham-se todas de L. bulgaricus e S. thermophilus.

5. Os lactobacilos isolados apresentaram um poder acidifican te bem superior aos estreptococos isolados.

6. Em apenas 25\% das associações L. bulgarïcus - S. thermophilus, realizadas nestes trabalho, observou-se produção de ácido superior à soma das produções individuais dos dois microrganismos componentes de cada associação. 
7. Um resfriamento rápido do iogurte em banho de gelo, ao final do período de incubação, retardou a pós-acidificação durante o período subsequente de armazenamento a $7^{\circ} \mathrm{C}$. 8. Durante o período de armazenamento dos iogurtes a $7^{\circ} \mathrm{C}$, após as primeiras 24 horas, há um decréscimo no número de bactérias láticas vivas.

9. Dentre os três iogurtes testados para o período de armazenamento a $7^{\circ} \mathrm{C}$, o iogurte obtido com a cultura mista constituída pelo Lactobacillus do iogurte comercial A com 0 S. thermophilus do iogurte D, apresentou uma pós-aciđificação mais lenta e acidez final menor, sendo pois a mais recomendada, dentre as testadas neste trabalho, para uma utilizacão comercial. 


\section{REFERENCIAS BIBLIOGRAFICAS}

ACCOLAS, J. P., BLOQUEL, R., DIDIENNE, R., REGNIER, J. Propriétes acidifiantes des bactéries lactiques thermophiles em relation avec la fabrication du yohourt. Le Lait, v. 52, n. 561-562, p. 1-23, 1977. ACCOLAS, J. P., VEAUX, M., AVCLAIR, J.. Estude des internactions entre diverses bactéries lactique thermophiles et mésophiles, en relation avec la fabrication des formages à pâte crite. Le Lait, v. 51, p. 1-23, 1971 .

ALEKSIEVA, V., MIRKOV, M. S.. Contamination of yoghurt with yeasts and moulds and their development in it. Food Science Technology Abstrat, v. 13, p. 292, 1981.

ANTUNES, L. A. F.. Caracterização da flora lática de leite cru. Campinas, 1985. 117p.. Tese (Doutorado) Fac. Eng. Alim. Agric., UNICAMP, 1985. 
BAUTISTA, F. S., DANIYVA, R. S., SPECK, M. L..

Identification of compounds causing symbiotic growth of Streptococcus thermophilus and Lactobacillus bulgaricus in milk. Journal Dairy Res., v. 33, p. 289-307, 1966.

BOTTAzzI, V. et alli. Continuous production of yogurt cultures and stimulation of Lactobacillus bulgaricus by formic acid. Milchwissenschaf, v. 26, n. 4, p. 214-219. "In: TERRA, N. N. et alli. Estudo do iogurte comercializa do em Santa Maria, RS. Revista do Centro de Ciêncais Rurais, v. 7, n. 3, p. 275-281, 1977 .

BOVILLANNE, C., DESMAZEAUD, M. J.. Classement de souches de Lactobacillus bulgaricus selon quelquer caracteres utilisés en fabrication du yougurt. Sciences de Aliments, v. 1 , p. 7-17, 1981

BRACQUART, P.. An agar medium for the differential

enumeration of Streptococcus thermophilus and Lactobacillus bulgaricus in yoghurt. Journal of Applied Bacteriology, v. 51, p. 303-305, 1981 .

BRASIL. Ministério da Agricultura. Secretária Nacional de Defesa Agropecuária Laboratório Nacional de Referência Animal. Métodos Analiticos Oficiais para Controle de Produtos de Origem Animal e seus Ingredientes. II. Métodos Físicos-Químicos, Brasília, 1981a, 1v.

BRASIL. Ministério da Agricultura. Secretária Nacional de De fesa Agropecuária. Laboratório Nacional de Referência ani mal. Métodos Analiticos Oficiais para Controle de Produ- 
tos de Origem Animal e seus Ingredientes. I. Métodos Microbiológicos. Brasília, 1981b, Iv.

CHAMBA, J. F., BONNAZ, G., BOVRE, P.. Comparisions de diverses méthods de denombremente de la flore acidificantes du lait cru. Le Lait, v. 61, p. 555-567, 1981 .

COKER, C. J., MARTLEY, F. G.. Selective enumeration of Thermophilic Lactobacilli in association with Streptococcus thermophilus. New Zealand Journal of Dairy Science and Technology, v. 17, n. 3, p. 269-272, 1982. DAVIDSON, C. M., CRONIN, F.. Medium for the selective enumeration of lactic acid bacteria from foods. Appl. Microbiol., v. 26, p. 439-440, 1973.

DAVIS, J. G., ASHTON, T. R., MCCASKILL, M.. Enumeration and viability of L. bulgaricus and S. thermophilus in yogurts. Dairy Ind., v. 36, n. 10, p. 569-573, 1971 . DAVIS, J. G.. Laboratory control of yogurt. Dairy Ind., v. 35, n. 9, p. 139-144, 1970 .

DAVIS, J. G., MCLACHLAN, T.. Yogurt in the united Kingdom: chemical and microbiological analysis. Dairy Ind., v. 39, p. 149-157, 177,1974 
DAVIS, J.G.. The microbiology of yoghurt. In:

Lactic acid bacteria in beverages and foods. Londres: Academic Press, 1975, p. 245-263

DEAK, T.. Nutriente médium suitable for counting and isolation of lactic acid bacteria. Konzerv-es Paprikaipar, v. 5, p. 167-170, 1973. In: "Food Sci. Technol. Ahst., v. 6, n. 12, p. 14, 1974 .

DEMAN, J. C., ROGOSA, M., SHARPE, M. F.. A medium for the cultivation of lactobacilli. Tournal of Applied Bacteriology, v. 23, p. 130-135, 1960 .

DEMETER, J. K.. Lactobacterioloqia Zaragosa, Editorial Acribia, 21p, 1969.

DIAZ, M. C.P., PADRÓN, A. G., MARANTE, R. A.. Development of microrganisms of hygienic interest in commercial yoghurts. Alimentaria, v. 26, n. 205, p. 51-55, 1989. DRIESSEN, R. M., KINGMA, F., STADHOUDERS, J.. Evidence that Lactobacillus bulgaricus in yogurt is stimulated by carbon dioxide produced by Streptococcus thermophilus. Neth. Milk. Dairy Journal, v. 36, p. 135, 1982a. DRIESSEN, R. M., UBBELS, J., STANDHOUDERS, J.. Continuous manufacture of yogurt. Biotechnology and Bioengineering, v. 19, p. $821,1982 \mathrm{~b}$.

DUITSCHAEVER, C. J., ARNOTT, D. R., BULLOCK, D. H. Quality evaluation of yoghurt produced commercially in ontário. J. Milk Food Tecnol., v. 35, p. 173-175, 1972. 
ELLIKER, P. R., ANDERSO, A. W., HANESSON, O.. An agar culture medium for lactic acid streptococci and lactobacil1i.J. Dairy Sci, v. 39, p. 1611-1612, 1956. EVANS, J. B., NIVEN Jr., C. F.: Nutrition of the heteriofermentative lactobacilli that cause greening of cured meat products. J. Bacteriol., v. 62, p. 599-603, 1951.

FERREIRA, C. L. L. F., CHAVES, J. B. P.. Caracterização do iogurte comercializado na zona da Mata, Minas Gerais. Revista do Instituto de Làtícinios Candido Tostes, v • 36, n: 218, p. 27-32, 1981

FERREIRA, C. L. L. F.. Elementos composicionais e aspectos nutritivos do leite e iogurte. Revista do Instituto de Latícinios Candido Tostes. v. 13, n. 200, p. 13-15, 1978 . GALESLOOT, TH. E., HASSING, F., VERINGA, H. A. Symbiosis in yoghurt (1). Stimulation of L. bulgaricus by a factor produced by S. thermophilus. Neth. Milk \& Dairy Journal, v. $22, p \cdot 50-63,1968$.

GARCIA, A. M.; FERNANDEZ, G. S.. Contaminating mycoflora in yoghurt: general aspects and special reference to/the genus Penicillium. Journal of Food Protection, v. 47, $\mathrm{n} \cdot 8, \mathrm{p} \cdot 629-636,1984$.

GARCIA, S.. Isolamento e seleção de culturas láticas para fabricação de queijos. Campinas, 1984, 89p.. Tese (Mes- 
trado) Fac. Eng. Alim. Agric., UNICAMF, .1984.

GARCIA, S., OLIVEIRA, J. S.. Isolamento e caracterização

de culturas láticas. Revista do Instituto de Latícinios

Candido Tostes, v. 40, n. 239, p. 19-30, 1985.

GINSLOV, B. O.. Modern trends in yogurt manufacture. s.

Afr. J. Dairy Technol., v. 2, p. 79-83, 1970 .

GOEL, M. C., KULSHRESTHA, D. C., MARTH, E. H., FRANCIS, D.

W., BRADSHAW, J. G., READ, R. B.. Fate of coliforms in

yogurt, buttermilk, sour cream, and cottage cheese

during refrigerated storage. Journal Milk Food

Technology, v. 34, p. 54, 1971 .

GREEN, M. D., IBE, S. N., 1987. Yeasts as primary

contaminants in yogurts produced commercially in Lagos

Nigéria. Journal Food Protection, v. 50, n. 3, p. 193-198, 1987.

HAMANN, W. T., MARTH, E. H.. Comparison of four differential and two general prupose media to enumerate Lactobacillus bulgaricus and Streptococcus thermophilus. Milchwissenschaff, v. 39, p. 147, 1984a.

HAMANN, W. T., MARTH, E. H.. Survival of Streptococcus

thermophilus and Lactobacillus bulgaricus in commercial and experimental yogurts. Journal of Food Protection, v. 47, no 10 , p. 781-786, $1984 \mathrm{~b}$. 
HAMDAM, I. Y。, KUNSMAN, J. E., DEANE, D。 D.. Acetaldehyde production by combined yogurt cultures. Journal Dairy Science, v. 54, p. 1080-1082, 1971.

HARRIGAN, W. F., MCCANCE, M. E.. Laboratory methods in food and dairy microbiology. London: Academic Press, 1976. $452 \mathrm{p}$

HULL, R. R., ROBERTS, A. V., MAYES, J. J.. Survival of Lactobacillus acidophilus in yoghurt. The Australian Journal of Dairy Technology, v. 39, n: 4, p. 164-166, 1984. HUMPHREYS, C. L., PLUNKETT, M.. Yogurt: a review of its manufacture. Dairy Sciende Abstr., v. 31, p. 607-622, 1969.

JACQMAIN-GOLDSMIT, E., DARAS-LHOIR, G.. A rapid method for differential enumeration of lactic acid bacteria in yoghurt. Revue des Fermentations et des Industries. Alimentaires, v. 39, n. 1, p. 9-11, 1984.

JOHNS, F. E., GORDON, J. F., SHAPTON, N.. The Separation from yoghurt cultures of lactobacilli and streptococci using reinforced clostridium agar at $\mathrm{pH} 5.5$ and plate count agar incorporating milk. Journal of the Society of Dairy Technology., v. 31, p. 209-212, 1978. JORDANO, R., MARTINEZ, P., GARRIDO, M. D. , JODRAL, M.. Changes of acidity and $\mathrm{pH}$ in commercial yoghurt. Alimentaria, v. 25, n'. 189, p. 61-64, 1988. 
KROGER, M.. Quality of yogurt. J. Dairy Science, v. 59, p. $344-350,1976$.

KROGER, M., WEAVER, J. C.. Confusion about yogurt compositional and otherwise. Journal Milk Food Technolgy, v. 36, p. 388-391. 1973 .

KURMANN, J. A.. Os fatores biológicos e técnicos da fabrucação do iogurte. In: CONGRESSO NACIONAL DE LATICINIOS, 4, 1977. Anais... 1977, p. 74-84.

LABRAPOULOS, A. E., COLLINS, W. F., STONE, W. K.. Starter culture effects on yogurt fermentation. Cultured Dairy Products Journal, v. 26, p. 359, 1982.

LEE, S. Y . VEDAMUTHU, E。 R., WASHAM, C. J . , REINBOLD, G. W.. An agar medium for the differential enumeration yogurt startes bacteria. Journal Milk Foode Technology, v. $37, \mathrm{n} \cdot 5, \mathrm{p} \cdot 272-276.1974$. LUCK, H., MOSTERT, J. F.. Pasteurisation of fermented milk products. S. Afr. Journal Dairy Technol. 'v . 3, n. 2, p. $75-80,1971$.

MARTH, E. R.. Standard methods for the examination of dairy products. Washington: American Public Health Association, D. C., $1978,416 \mathrm{p}$.

MARTINS, J. F. P., LUCHESE, R. H.. Acidificação no processą mento e no armazenamento como parâmetros para a seleção de associações de Streptococcus thermophilus e Lactobacillus 
bulgaricus para o processamento de iogurte. Revista do Instituto de Laticínios Candido Tostes, v. 43, n. 255, p. $32-34,1988 a$.

MARTINS, J.F. P., LUCHESE, R. H.. Determinação da compatibilidade de crescimento associativo entre cepas de Lactobacillus bulgaricus e Streptococcus thermophilus. Revista do Instituto de Laticínios Candido Tostes, v. 43, n: 256, p. 1i-13, $1988 \mathrm{~b}$

MATALON, M. E., SANDINE, W. F.. Improved media for differentiation of rods and cocci in yogurt. Journal of Dairy Science, v. 69, n. 10, p. 2569-2576, 1986.

MEILKEJOHN, P. G.. How to achieve better yoghurt vicosity. Cultured Dairy Products Journal, v. 12, p. 5-7. 1977.

MERMLSTEIN, N. H.. Advanced bulk starter medium improves fermentation processes. Food Technology, v. 36 , n: 8 , p. 69,1982 .

MINOR, T. E., MARTH, E. R.. Fate of Staphylococcus aureos in cultured buttermilk, sour cream, and yogurt during storage. Journal Milk Food Technology, v. 35, p. 302, 1972 .

MOCQUOT, O., HUREL, C.. The selection and use of some micro-organisms for the manufacture of fermented and acidified milk products. Soc. Dairy Technol. Journal, v. 23, p. 130-146, 1970 . 
MOON, N. J., REINBOLD, G. W.. Commensalism and competition in mixed cultures of L. bulgaricus and $S$. thermophilus. Journal Milk Food Technology, v. 39, p. 337-341, 1976.

MOON, N. J., REINBOLD, G. W: , HAMMOND, E. G.. Acid production of mixed cultures of Lactobacilus bulgaricus and Streptococcus thermophilus as an indicator of growth at 37, 21 and $14^{\circ} \mathrm{C}$. Journal Dairy Science, v. 58, p. 787, 1975. MORAES, J. M., PASSOS, L. A. S.. Isolamento de Lactobacillus bulgaricus e Streptococcus thermophilus a partir de iogurte de mercado. Revista do Instituto de Laticinios Candido Tostes, v. 34, n. 206, p. 15-17, 1979.

OTTOGALLI, G., GALLI, A.. A differential medium for

Streptococcus thermophilus in dairy products. In:

"International Dairy Congress", 20, 1978. Anais. . 1978, p. 350 .

PETTE, J. W., LOLKEMA, H.. Factors influencing the proportion of streptococci and lactobacilli in a yogurt culture. Netherland Milk Dairy Journal, v. 5, p. 14-26, 1951.

PETTE, J. W., LOLKEMA, H.. Yogurt II Growth Stimulating factors for S. thermophilus milk. Dairy Journal, v. 4, p. 209, 1950a.

PETTE, J. W., LOLKEMA, H.. Yogurt IV. Het even wich der bacteriessorten in yoghurt. Netherland Milk Dairy Journal, v. 5, p. 14-26, $1950 \mathrm{~b}$. 
PETTE, J. W., LOLKEMA, H.. Yoghurt I. Symbiosis and antibiosis in mixed cultures of Lactobacillus bulgaricus and Streptococcus thermophilus. Neth. Milk Dairy Jounral, $\mathrm{v}, 4, \mathrm{p} .197,1950 \mathrm{c}$.

PETTE, J. W., LOLKEMA, H.. Yogurt III. Zuurvorming en aromavorming in yoghurt. Neth Milk. Dairy Journal, v. 5, p. 14-26, 1950d.

PORUBCAN, R. S., SELLARS, R. L.. An agar medium for the differentiation of L. bulgaricus and $S$. thermophilus. Journal Dairy Science, v. 56, p. 634, 1973.

PREIXENS, S., SANCHO, J.. Development of coliforms in natural yoghurt. Alimentaria, v. 187, p. 33-37, 1987. RADKE-MITCHELL, L. C., SANDINE, W. E.. Associative growth and differential enumeration of Streptococcus thermophilus and Lactobacillus bulgaricus:" a review. Journal Food Protection, v. 47, p. 245, 1984.

RADKE-MITCHELL, L. C., SANDINE, W. E.. Influence of temperature on associative growth of Streptococcus thermophilus and Lactobacillus bulgaricus. Journal of Dairy Science, v. 69, n. 10, p. 2558-2568, 1986. RASIC, J. L., KURMANN, J. A.. Yogurt Scientific gronds. technology, manufacture an preparation. Copenhagem: Technical Dairy Publishing House, 1978. 
RASIC, J., MITIC, S.. Contribution a l'étude de l'activite antibiotique des sounches de culture de yoghurt. Le Lait, v。 43, p. 489, 1963.

RICHMOND, M. L., CHANDAN, R. C., STINE, C. M.. Yogurt - a compositional survey in the greater lansing area. Journal of Food Protection, v. 42, no 5, p. 424-426. 1979 .

ROBINSON, K. R., TAMINE, A. Y.. Quality appraisal of y.oghurt. Journal of the Society of Dairy Technology, v. 29, n. 3, p. 148-155, 1976

ROGOSA, M., MITCHELL, J.A., WISEMAN, R. F.. A selective medium for the isolation and enumeration of oral and fecal lactobacilli. Journal Bacteriology, v. 62, p. $132-133,1951$.

ROHM, H., LECHNER, F., LEHNER, M.. Microflora of austrian natural-set yogurt. Journal of Food Protection, v. 53, n. 6, p. $478-480,1990$.

SALINAS, J. R.. Development of essential microflora of commercial yoghurt during storage. Archivos de Zootecnia v. 33, n. 127, p. 237-248, 1984a.

SALINAS, J. R.. Yoghurt contamination with yeasts and moulds. Archivos de Zootécnia, v. 33, n. 125, p. 97-103, $1984 \mathrm{~b}$

SALJI, J. P., ISMAIL, A. A. Effect of initial acidity of plain yoghurt on acidity changes during refrigerated 
torage. Journal of Food Science, v. 48, n. 1, p. 258-259, 1983 .

SANDINE, W. E., MATALON, M. E.. Lactobacillus bulgaricus, Streprococcus thermophilus e yogurt: a review. Cultured Dairy Products Journal, p. 6-12, 1986.

SELLARS; R. L., BABEL, F. J.. Cultures for the manufacture of dairy products. Chr. Hansen's Laboratory, Inc. Milwaukee, Wis. 1970.

SHANKAR, P. A., DAVIES, F. L. Proteinase and peptidase activites of yogurt starter bacteria. in: INTL. DAIRY CONGR., 20 th, 1978, Paris. Anais... 1978, E. 1467. SHANKAR, P. A., DAVIES, F. L.. A Note on the suppression of Lactobacillus bulgaricus in media containing $\beta$. glycerophosphate and application of such media to selective isolation of Streptococcus thermophilus from yoghurt. Journal of the Society of Dairy Technology, v. 30, n. 1, p. $28-30,1977 \mathrm{a}$.

SHANKAR, P. A., DAVIES, F. L.. Aminoacid and peptide utilization by $S$. thermophilus in relations to yogurt manufacture. Journal Applied Bacteriology, v. 43, p. 8, $1977 \mathrm{~b}$.

SILVA, J. C.. Leites fermentados: iogurte e acidófilo. Revista do Instituto de Laticínios CAndido Tostes, v. 29 , n. 174-175, p. 70-81, 1974 .

SINGH, J.. Inhibition of growth of spoilage microrganisms by S. thermophilus and L. bulgaricus in cow, buffalo and 
goat milk. Journal Food Protection, v. 46, p. 497, 1983.

SINGH, J., SHARMA, D. K.. Yoghurt starters in skim milks. 1. acid and flavour production and proteolytic activity by yóghurt starters. Cultured Dairy Products Journal, v. 2, p. 22-25, 1982 .

SINHA, R. P., MODLER, H. W., EMMONS, D. B., Changes in acidity and starter bacteria in commercial yogurts during storage. Cultured Dairy Products Journal, v • 24, n. 2, p. 12-14, 16, 1989 .

SOULIDES, D. A.. Lactose fermentting yeasts in yogurt and their effect upon the product and the bacterial flora. Appl. Microbiol, v. 4, p. 274-276, 1986.

SPECK, M. L.. Compendium methods for the microbiological. examination of foods. Washington: American Public Health Association Washington, D. C., 1976, 702 p. STOCKLIN, P.. Production and hardling of yogurt on a commercial scale. Cultured Dairy Prod. J., v. 4, n. 3, p. 6-10, 1969 .

SURIYARACHCHI, V. R., FLEET, G. H.. Occurrence and growth of yeasts in yogurts. Applied and Environmental Microbiology, v. 412, n. 3, p. 574-579, 1981. TAMINE, A. Y., DAVIES, G., HAMILTON, M. P.. The quality of yoghurt on retail sale in arshire. Part 1. Chemical and microbiological evaluation. Dairy Industries International. 
v. 52 , n. 6, p. $19-21,1987$.

TAMINE, A. Y., DEETH, H. C.. Yoghurt: Technology and biochemistry. Journal Food Protection, v. 43, p. 939-977, 1980.

TERGAZHI, B. E., SANDINE, W. E.. Improved medium for lactic streptococci and their bacteriophages. Applied and Environmental Microbiology, v. 29, p. 807-813, 1975. TERRA, N. N., MUSSOI, E., BRUM, M. A.. Estudo do iogurte co mercializado em Santa Maria, RS. Revista do Centro de Ciências Rurais, v. 7, n. 3, p. 275-281, 1977. VERINGA, H. A., GALESLOOT, T. E., DAVELAAR, H.. Symbiosis in yoghurt (II). Isolation and identification of a growth factor Lactobacillus bulgaricus produced by Streptococcus thermophilus. Neth Milk \& Dairy J., v. 22, p. $114-120,1968$.

VIEIRA, S. D. A.. A utilização de culturas lāticas na indústria de laticínios. Revista do Instituto de Laticínios. Candido Tostes, v. 35, n. 215, p. 29-36, 1981. WELKER, A. L., Importance of monitoring acid development in swiss-style yogurt. Cultured Dairy Products Journal, p. 23-26, 1986 . YAZICIOGLU, A., YILMAZ, N.. Studies on the microflora of yoghurt and its antimicrobial action. Dairy Science. Abstr., v. 28, p. 252, 1966. 